\title{
Review \\ SSAO/VAP-1 in Cerebrovascular Disorders: A Potential Therapeutic Target for Stroke and Alzheimer's Disease
}

\author{
Mercedes Unzeta ${ }^{1}$, Mar Hernàndez-Guillamon ${ }^{2, *}$, Ping Sun ${ }^{3}(-)$ and Montse Solé ${ }^{2}(\mathbb{D}$ \\ 1 Department of Biochemistry and Molecular Biology, Institute of Neurosciences, Universitat Auònoma de \\ Barcelona, 08193 Barcelona, Spain; Mercedes.Unzeta@uab.es \\ 2 Neurovascular Research Laboratory, Vall d'Hebron Research Institute, Universitat Autònoma de Barcelona, \\ 08035 Barcelona, Spain; spmontse2@gmail.com \\ 3 Department of Neurology, Pittsburgh Institute of Brain Disorders and Recovery, University of Pittsburgh \\ School of Medicine, Pittsburgh, PA 15213, USA; sunp@upmc.edu \\ * Correspondence: mar.hernandez.guillamon@vhir.org; Tel.: +34-934-896-766
}

Citation: Unzeta, M.;

Hernàndez-Guillamon, M.; Sun, P.;

Solé, M. SSAO/VAP-1 in

Cerebrovascular Disorders: A

Potential Therapeutic Target for

Stroke and Alzheimer's Disease. Int.

J. Mol. Sci. 2021, 22, 3365. https://

doi.org/10.3390/ijms22073365

Academic Editor: Amal Kaddoumi

Received: 21 February 2021

Accepted: 23 March 2021

Published: 25 March 2021

Publisher's Note: MDPI stays neutral with regard to jurisdictional claims in published maps and institutional affiliations.

Copyright: (c) 2021 by the authors. Licensee MDPI, Basel, Switzerland. This article is an open access article distributed under the terms and conditions of the Creative Commons Attribution (CC BY) license (https:/ / creativecommons.org/licenses/by/ $4.0 /)$

Abstract: The semicarbazide-sensitive amine oxidase (SSAO), also known as vascular adhesion protein-1 (VAP-1) or primary amine oxidase (PrAO), is a deaminating enzyme highly expressed in vessels that generates harmful products as a result of its enzymatic activity. As a multifunctional enzyme, it is also involved in inflammation through its ability to bind and promote the transmigration of circulating leukocytes into inflamed tissues. Inflammation is present in different systemic and cerebral diseases, including stroke and Alzheimer's disease (AD). These pathologies show important affectations on cerebral vessels, together with increased SSAO levels. This review summarizes the main roles of SSAO/VAP-1 in human physiology and pathophysiology and discusses the mechanisms by which it can affect the onset and progression of both stroke and AD. As there is an evident interrelationship between stroke and $\mathrm{AD}$, basically through the vascular system dysfunction, the possibility that SSAO/VAP-1 could be involved in the transition between these two pathologies is suggested. Hence, its inhibition is proposed to be an interesting therapeutical approach to the brain damage induced in these both cerebral pathologies.

Keywords: SSAO/VAP-1; stroke; Alzheimer's disease; vascular damage; blood-brain barrier dysfunction; neurovascular unit; inflammation; oxidative stress

\section{Introduction}

\subsection{SSAO: An Amine Oxidase}

Amine oxidases (AOs) are a group of enzymes that catalyze the oxidative deamination of various amines from the endogenous and xenobiotic origin, as well as those present in the diet. According to their attached cofactors, the amine oxidases include the following categories: (i) flavin adenine dinucleotide (FAD)-containing enzymes (E.C. 1.4.3.4) include polyamine oxidase (PAO) (E.C. 1.5.3.11) [1], and both isoforms of Monoamine oxidase (MAO-A and -B), which participate in the metabolism of biogenic amines with neurotransmitter functions [2,3]; and (ii) topa-quinone (TPQ) or lysine tyrosyl quinone (LTQ)-containing enzymes, which makes them easily inhibited by carbonyl compounds, such as semicarbazide, including diamine oxidase (DAO) (E.C. 1.4.3.22), lysyl oxidase (LOX) (E.C. 1.4.3.13), and soluble and membrane-bound semicarbazide sensitive amine oxidase (SSAO) (E.C. 1.4.3.21) [4-6].

All AOs are able to catalyze the oxidative deamination of different amines, according to the following reaction:

$$
\mathrm{R}-\mathrm{CH}_{2}-\mathrm{NH}_{2}+\mathrm{O}_{2}+\mathrm{H}_{2} \mathrm{O} \rightarrow \mathrm{R}-\mathrm{CHO}+\mathrm{NH}_{3}+\mathrm{H}_{2} \mathrm{O}_{2}
$$

SSAO is multifunctional. It can metabolize the deamination of primary amines exclusively, and its functions depend on the tissue that expresses it [7], as listed in Table 1. Some 
SSAO substrates, such as benzylamine, show an overlap with MAO substrates, responsible for the primary, secondary, and tertiary amine metabolism, but the physiological substrates methylamine and aminoacetone are exclusively metabolized by SSAO [8-10]. Physiologically, methylamine can be derived from the metabolism of epinephrine [11], adrenaline [12], creatine, creatinine [13,14], sarcosine and choline [15-17]. Methylamine may also come from the digestion of food and beverages or cigarette smoking [18]. Aminoacetone, however, is a metabolic product of glycine and threonine [19]. SSAO can catalyze the deamination of methylamine and aminoacetone to generate not only hydrogen peroxide $\left(\mathrm{H}_{2} \mathrm{O}_{2}\right)$ and ammonia but also formaldehyde and methylglyoxal, respectively.

When overproduced, the metabolites generated by the deamination of SSAO substrates may constitute potentially hazardous products; thus, the inhibition of SSAO activity may be beneficial under some pathological conditions, which will be detailed further below. Many chemicals can inhibit both SSAO and MAO activities [20]. For example, the hydrazine derivatives phenelzine, phenylhydrazine, hydralazine, benserazide, and carbidopa, can inhibit SSAO activity, and some of them also inhibit MAO activity [20,21]. Lately, the hypothesis that SSAO inhibition could become a therapeutic target in several diseases has significantly increased the design and synthesis of new specific molecules that are able to modulate or inhibit its activity [22-26].

Molecular modeling studies showed that the membrane-bound SSAO in humans is a $180 \mathrm{kDa}$ homodimeric glycoprotein composed of two identical $90 \mathrm{kDa}$ monomer subunits. It consists of a short membrane spinning domain and three catalytically active extracellular copper-containing amine oxidase domains $[27,28]$. Surprisingly, the cloning of a novel cell adhesion molecule, endothelial vascular adhesion protein-1 (VAP-1) cDNA, shows that VAP-1 not only has SSAO activity but is also significantly identical to copper-containing amine oxidase [29]. Since then, VAP-1 has been considered to have dual functions and is defined as a new type of adhesion molecule with both cell adhesion function and SSAO enzyme activity, as SSAO/VAP-1 [30].

Table 1. Semicarbazide-sensitive amine oxidase (SSAO)/ vascular adhesion protein-1 (VAP-1) tissue localization, cell type expression, physiological substrates proved to be metabolized by these tissues and physiological function. Note the absence of SSAO/VAP-1 expression in cerebral parenchymal cells (neurons and glia). Benzylamine is a non-physiological substrate of SSAO metabolized by SSAOs from different origins. Data are summarized from [7-19,31-44].

\begin{tabular}{|c|c|c|c|}
\hline Tissue & Cell Type & Substrate & Function \\
\hline $\begin{array}{l}\text { Cerebrovascular tissue (meninges } \\
\text { and microvessels) } \\
\text { (human, rabbit, mouse, bovine) }\end{array}$ & $\begin{array}{l}\text { Endothelial cells } \\
\text { Smooth muscle cells }\end{array}$ & $\begin{array}{l}\text { Methylamine (derived from } \\
\text { epinephrine, adrenaline, creatine, } \\
\text { sarcosine and choline) } \\
\text { aminoacetone (derived from } \\
\text { glycine and threonine) }\end{array}$ & $\begin{array}{c}\text { Scavenger of endogenous dietary } \\
\text { amines } \\
\text { Generation of } \mathrm{H}_{2} \mathrm{O}_{2} \text { as a signaling } \\
\text { molecule } \\
\text { Leukocyte trafficking under } \\
\text { inflammation }\end{array}$ \\
\hline $\begin{array}{l}\text { Vascularized tissues (heart, } \\
\text { kidney, lung, intestine, liver, } \\
\text { retina and lymph nodes) and } \\
\text { blood vessels (human, pig, rat, } \\
\text { rabbit, bovine) }\end{array}$ & $\begin{array}{c}\text { Endothelial cells } \\
\text { Smooth muscle cells } \\
\text { Pericytes }\end{array}$ & $\begin{array}{l}\text { Phenylethylamine } \\
\text { Dopamine } \\
\text { Methylamine } \\
\text { Tyramine } \\
\text { Tryptamine }\end{array}$ & $\begin{array}{c}\text { Metabolism of physiological } \\
\text { circulating amines and xenobiotic } \\
\text { ones } \\
\text { Leukocyte binding and } \\
\text { extravasation under inflammatory } \\
\text { conditions }\end{array}$ \\
\hline $\begin{array}{l}\text { Adipose tissue } \\
\text { (human and rat) }\end{array}$ & Adipocytes (white and brown) & $\begin{array}{l}\text { Various endogenous and } \\
\text { exogenous amines }\end{array}$ & $\begin{array}{l}\text { Metabolism of endogenous } \\
\text { amines } \\
\text { Insulinomimetic effects through } \\
\text { the generation of } \mathrm{H}_{2} \mathrm{O}_{2}\end{array}$ \\
\hline Ureter and vas deferens & Non-vascular smooth muscle cells & Dopamine & $\begin{array}{l}\text { Metabolism of physiological } \\
\text { amines and xenobiotic ones }\end{array}$ \\
\hline Endometrium (human) & Pericytes & Methylamine & Recruiting innate immune cells \\
\hline Skin (guinea pig) & Fibroblasts & $\begin{array}{l}\text { Histamine } \\
\text { 1-4 Methylhistamine }\end{array}$ & $\begin{array}{l}\text { Metabolism of physiological } \\
\text { amines and xenobiotic ones }\end{array}$ \\
\hline $\begin{array}{l}\text { Dental pulp } \\
\text { (human, pig) }\end{array}$ & Odontoblasts & $\begin{array}{c}\text { Serotonin } \\
\text { Phenylethylamine } \\
\text { Tyramine } \\
\text { Tryptamine }\end{array}$ & $\begin{array}{l}\text { Contribution to inflammatory } \\
\text { response in dental pulp (pulpitis) }\end{array}$ \\
\hline
\end{tabular}




\subsection{SSAO/VAP-1: Expression and Tissular Localization}

SSAO/VAP-1 is present in a wide number of mammalian species [31], both as a membrane-bound form and also as a soluble form in blood plasma [7]. High SSAO activity is observed to be associated with vascularized tissues [32], and specifically in blood vessels [33], where it is expressed by smooth muscle cells and endothelial cells [34].

Human SSAO/VAP-1, as in other species, is widely distributed in almost all vascularized tissues and adipose tissue. In humans, the presence of the SSAO enzyme also has been specifically reported in vascular endothelial cells and smooth muscle cells extracted from skin, heart, liver, kidney, and brain [35,36]. Its presence has also been described in pig dental pulp [37], where it is able to metabolize serotonin [38,39]. Regarding the cerebrovascular tissue, its presence in human and bovine brain meninges and microvessels, as well as in retina and eye sclera, were confirmed by using a rabbit anti-bovine lung SSAO/VAP-1 polyclonal antibody [40,41,45-47].

At the subcellular level, SSAO/VAP-1 located at the plasmatic cell membrane appears randomly distributed in structures named caveolae [48,49], constituting the lipid rafts. Whether it has a specific function related to this localization needs to be addressed, as lipid rafts are specialized membrane microdomains with a role in signal transduction that assemble signaling molecules and influence membrane protein trafficking [50].

\subsection{SSAO/VAP-1 Physiological Functions}

Up to now, several functions of SSAO/VAP-1 have been described under physiological conditions, as summarized in Table 1, related to its ability to metabolize primary amines: the protection against endogenous/xenobiotic amines, the local generation of signaling molecules, glucose transportation, and leukocyte trafficking under inflammation [8,51].

\subsubsection{Amine Deamination}

The first main function attributed to SSAO/VAP-1 was based on its enzymatic activity, and it was associated with the homeostatic removal or scavenging of physiological active endogenous and xenobiotic amines, which are potentially hazardous [52]. SSAO deamination of its substrates can reduce the biological activities of the substrates. Moreover, all the catalytic products of SSAO have biological activities and may have important roles at physiological concentrations, contributing to the other functions attributed to SSAO/VAP-1. In this regard, low concentrations of $\mathrm{H}_{2} \mathrm{O}_{2}$ can behave as intracellular second messengers to participate in ligand stimulation, cell growth or cell death regulation, or NF- $\mathrm{kB}$ signaling activation. Subsequently, NF- $\mathrm{kB}$ activation modulates the expression of many other genes, such as MMPs, cytokines, chemokines, and vascular cell adhesion molecules [5,53]. This signaling is also involved in angiogenesis and cellular differentiation. It has also been demonstrated that $\mathrm{H}_{2} \mathrm{O}_{2}$ can activate mitogen-activated protein kinase (MAPK) as well as the c-Jun amino-terminal kinase (JNK) [54]. Furthermore, immunohistochemical studies indicate that in most human peripheral tissues, SSAO/VAP-1 might participate in the regulation of physiological processes through $\mathrm{H}_{2} \mathrm{O}_{2}$ generation [36].

\subsubsection{Activation of Glucose Transport}

In isolated rat cardiac myocytes and rat adipocytes endosomal vesicles, insulin can induce the recruitment of the intracellular glucose transporters (GLUT4) and (GLUT1) [55] Vesicle immunoisolation analysis indicated that GLUT4-containing vesicles from rat adipocytes contain substantial levels of SSAO activity and immunoreactive SSAO/VAP-1 protein. Furthermore, it has been reported that the SSAO substrate benzylamine could accelerate the transportation of glucose in the presence of low concentrations of vanadate in isolated adipocytes from rats. This effect of benzylamine and vanadate on glucose transport was totally abolished in the presence of semicarbazide, used as an SSAO inhibitor $[56,57]$. Later on, it was reported that some SSAO substrates stimulate glucose transport and inhibit lipolysis in human adipocytes, which confirmed the insulin-mimetic action of this protein, depending on its enzymatic activity [42]. 


\subsubsection{Leukocyte Adhesion Function under Inflammation}

SSAO/VAP-1 can act as an adhesion protein in the leukocyte trafficking process [43,58-61]. Firstly, VAP-1 was reported to be involved in the human lymphocyte trafficking to high endothelial venules (HEVs) in the tonsils, peripheral lymph nodes (PLN), and inflamed synovia [29]. Besides, SSAO/VAP-1 was also found to have increased expression at the inflammation sites to control the recirculation of lymphocytes and the entry of leukocytes [43]. By establishing the primary endothelial cells with the expression of enzymatically active SSAO/VAP-1, firm evidence demonstrated that the SSAO activity of VAP-1 was directly involved in the rolling and transmigration steps during leukocyte adhesion [5,44]. SSAO/VAP-1 participates in these processes by acting as an adhesion protein but also through the SSAO-catalyzed end products [62]. In this regard, the $\mathrm{H}_{2} \mathrm{O}_{2}$ generated by its enzymatic activity is able to induce the expression of other endothelial adhesion molecules, such as MadCAM-1, E-selectin, P-selectin and CXCL8, through the activation of NF-kB [63]. This dual function of SSAO/VAP-1 also results in a different selectivity in the type of leukocytes to bind, which also depends on the organ and the type of inflammatory stimulus, as detailed in Table 2 . It has been reported that lipopolysaccharide (LPS), interleukin $1 \beta$ (IL-1 $\beta$ ), interferon- $\gamma$ (IFN- $\gamma$ ) and tumor necrosis factor- $\alpha$ (TNF- $\alpha$ ) are the inflammatory mediators responsible of the SSAO/VAP-1 migration from intracellular vesicles to the plasma membrane [64]. Once there, different adhesion molecules facilitate leukocytes binding to SSAO/VAP-1 for a successful emigration cascade, such as peripheral lymph node addressin (PNAd), vascular cell adhesion molecule 1 (VCAM-1), or intracellular adhesion molecules (ICAM-1, ICAM-2) [43].

Table 2. SSAO/VAP-1 is involved in the binding/transmigration of different types of leukocytes, but not of other types. This selectivity also depends on the organ studied and the inflammatory stimulus.

\begin{tabular}{|c|c|c|c|c|}
\hline Inflammatory Stimulus & Organ/Tissue & $\begin{array}{l}\text { Type of Leukocytes } \\
\text { Bound by SSAO/VAP-1 }\end{array}$ & $\begin{array}{c}\text { Type of Leukocytes not Bound } \\
\text { by SSAO/VAP-1 }\end{array}$ & Reference \\
\hline Ischemia/reperfusion & Kidney & Neutrophils & Macrophages/T-lymphocytes & [65] \\
\hline Postischemic inflammation & Brain & Neutrophils & $\begin{array}{ll}1 \\
-\end{array}$ & [66] \\
\hline Subarachnoid hemorrhage & Brain & Neutrophils & - & [67] \\
\hline Intracerebral hemorrhage & Brain & Neutrophils & - & [68] \\
\hline Peritonitis & Peritoneum & Granulocytes & - & \\
\hline Air pouch inflammation & Subcutaneous & Monocytes/lymphocytes & - & [69] \\
\hline LPS & Brain & Neutrophils & - & [70] \\
\hline LPS, Klebsiella pneumoniae & Lungs & $\begin{array}{c}\text { Polymorphonuclear cells, } \\
\text { neutrophils }\end{array}$ & - & [71] \\
\hline Acute liver failure & Liver & Leukocytes & Monocytes & [72] \\
\hline ConA hepatitis & Liver & CD4+ Th2 cells & - & [73] \\
\hline $\begin{array}{l}\text { Hepatic chronic } \\
\text { inflammation and fibrosis }\end{array}$ & Liver & CD16+ monocytes & - & [74] \\
\hline Liver inflammation & Liver & CD4+ T cell & - & [75] \\
\hline Liver allograft rejection & Liver & $\begin{array}{l}\text { CD4+ and CD8+ } \\
\text { lymphocytes }\end{array}$ & - & {$[76,77]$} \\
\hline Tumors (adhesion function) & Skin & CD45+, CD3+, CD8+ & $\begin{array}{c}\text { CD4+, T-reg cells, Type2 } \\
\text { macrophages, GR-1+CD11b+ }\end{array}$ & [78] \\
\hline Tumors (enzymatic function) & Skin & $\begin{array}{l}\mathrm{CD} 45+, \mathrm{CD} 8+, \mathrm{CD} 11 \mathrm{~b}+, \\
\text { granulocytes, }\end{array}$ & CD4+, type2 macrophages & [78] \\
\hline $\begin{array}{l}\text { Cytokine-induced } \\
\text { angiogenesis }\end{array}$ & Eyes & $\begin{array}{l}\text { CD11b+ cells, } \\
\text { granulocytes }\end{array}$ & - & [79] \\
\hline Diabetic retinopathy & Eyes & Leukocytes & - & [80] \\
\hline Uveitis & Eyes & CD45+ & - & [81] \\
\hline In vitro & Endothelial cells & Lymphocytes, T-killer cells & Neutrophils, monocytes & [82] \\
\hline In vitro & Endothelial cells & $\begin{array}{l}\text { Polymorphonuclear } \\
\text { leukocytes }\end{array}$ & - & [83] \\
\hline AOC3 knockout & Adipose tissue & $\begin{array}{c}\text { CD45+, T cells, } \\
\text { macrophages, natural } \\
\text { killer }\end{array}$ & - & [84] \\
\hline
\end{tabular}




\subsection{SSAO/VAP-1 Involvement in Pathological Conditions}

The physiological functions of SSAO/VAP-1 can lead to a harmful situation when its levels are increased, as summarized in Table 3. Due to the potentially hazardous activity of the SSAO activity products, increased activity of this enzyme is associated with diverse human pathological processes. The SSAO metabolic products, such as formaldehyde or methylglyoxal, are toxic at high concentrations, especially in blood vessels $[18,85]$. In this regard, the in vitro treatment of vascular cells with methylamine, which generates formaldehyde, induces a dose- and time-dependent cytotoxic effect and activates apoptotic cell death through the tumor suppressor protein p53 activation, inducing PUMA-alpha expression, altering the mitochondrial Bcl-2 family proteins, and activating final effector caspases [86]. In the case of the substrate aminoacetone, the generation of methylglyoxal by SSAO activity has been implicated in vascular alterations, and it is a well-known precursor of advanced glycation end products (AGEs), which are involved in diabetic complications and vascular degeneration $[87,88]$.

Table 3. Physiological functions of SSAO/VAP-1 and pathological effects associated with these functions in situations where the enzyme is overexpressed. Data are summarized from [7-9,16-18,31-34,78,87-104].

\begin{tabular}{|c|c|c|}
\hline Physiological Function & $\begin{array}{c}\text { Pathological Effect Upon SSAO/VAP-1 } \\
\text { Overexpression }\end{array}$ & Involvement in Pathologies \\
\hline \multirow{7}{*}{$\begin{array}{l}\text { Oxidative deamination of primary } \\
\text { amines of endogenous and xenobiotic } \\
\text { origin } \\
\text { Molecular signaling through } \mathrm{H}_{2} \mathrm{O}_{2} \\
\text { generation }\end{array}$} & Toxicity of metabolic products & Stroke \\
\hline & (formaldehyde, methylglyoxal, $\mathrm{H}_{2} \mathrm{O}_{2}$ ) & $\mathrm{AD}$ \\
\hline & Protein cross-linking and $A \beta$ aggregation & Diabetes \\
\hline & Oxidative stress & Atherosclerosis \\
\hline & AGEs generation & Congestive heart failure \\
\hline & Inflammation & Fibrotic liver disease \\
\hline & Pathological angiogenesis & $\begin{array}{c}\text { Cancer } \\
\text { Age-related macular degeneration }\end{array}$ \\
\hline $\begin{array}{l}\text { Leukocyte trafficking under } \\
\text { inflammatory conditions }\end{array}$ & Excessive inflammatory response & MS \\
\hline $\begin{array}{l}\text { Insulinomimetic action by recruitment of } \\
\text { GLUT4 receptors to the cell membrane }\end{array}$ & Unknown & Unknown \\
\hline
\end{tabular}

In humans and other species, soluble SSAO/VAP-1 exists in the serum of healthy adults $[89,90]$, but its levels are found to increase in several pathological conditions. Experiments performed in adipocytes evidenced that soluble SSAO/VAP-1 could be shed from the membrane-bound form depending on a matrix metalloproteinase (MMP) activity in diabetic and obese animals [105]. It seems that under pathological conditions, soluble SSAO/VAP-1 originates from adipocytes, endothelial cells and smooth muscle cells [106], but given that various cellular sources can secrete different types of MMPs, such as neurons, cerebral microvascular endothelial cells, astrocytes, and inflamed neutrophils, which kinds of MMPs participate in the shedding of soluble SSAO/VAP-1 still warrant future investigation.

Plasma soluble SSAO/VAP-1 is increased in various systemic diseases: in diabetes, atherosclerosis [107-110], congestive heart failure [91] and non-diabetic morbidity obesity [111]. Moreover, it has also been described that the soluble SSAO/VAP-1 is increased in malignant hypertension [51], inflammatory diseases (cirrhotic liver inflammation) [89], and retinopathies associated with diabetes mellitus [112]. The specific mechanisms regulating the soluble plasmatic SSAO/VAP-1 and activity increase in these pathologic conditions are still not fully elucidated. Since soluble SSAO/VAP-1 may be derived from the membranebound form, the enhanced SSAO activity in plasma may be attributed to upregulated expression of membrane-bound SSAO/VAP-1 in diabetic patients [17] in response to inflammation [89]. The increasing prevalence of chronic inflammatory and autoimmune diseases associated with the aging population points out the interest in developing therapies directed against SSAO/VAP-1 for the treatment of chronic inflammatory diseases [113]. 
On the other hand, plasma SSAO activity was found to decrease in severely burnt or cancer patients [114]. Using an experimental model of breast cancer in rats induced by 7,12-dimethylbenz(alpha)anthracene (DMBA), a decreasing SSAO activity was observed and correlated with cancer malignancy [115]. However, it was described that high levels of SSAO/VAP-1 are closely linked to alternative M2 macrophage activation during human glioma progression [116]. Moreover, the SSAO/VAP-1 expression in different astrocytoma grades and its correlation with clinicopathological features as well as prognosis of astrocytoma patients was studied. The expression of this enzyme was assayed by immunohistochemistry, and the level of SSAO/VAP-1 was found significantly higher in diffuse astrocytoma than those of pilocytic astrocytoma. Therefore, the authors concluded that SSAO/VAP-1 could be a promising prognostic biomarker in human astrocytoma [117].

SSAO/VAP-1 also has been found altered in central nervous system (CNS) pathologies. In humans, the concentration of soluble SSAO/VAP-1 in serum is significantly higher in multiple sclerosis (MS) patients with ongoing inflammatory activity, as demonstrated by gadolinium-enhancing MRI lesions [118]. Results suggest that SSAO/VAP-1 may participate in controlling leukocyte entry into the inflamed brain in this pathologic condition. In addition, the expression of membrane-bound SSAO/VAP-1 has been studied in focal rat models of experimental autoimmune encephalomyelitis (EAE) mimicking MS. Results reveal that SSAO/VAP-1 is expressed and is functionally active in vasculature within the induced focal EAE lesions during the acute phase of inflammation, and it remains expressed after the acute inflammation has subsided. These data support that SSAO/VAP-1 is actively involved in the development of inflammatory CNS lesions [119], thus becoming an interesting target to study its involvement in human vascular and inflammatory pathologies [120]. The involvement of SSAO/VAP-1 in stroke and AD, where its levels are found also elevated, will be discussed in-depth in the following sections.

\section{Cerebrovascular Dysfunction in Stroke and AD}

\subsection{The BBB and Cerebrovascular Dysfunction}

Brain endothelial cells are unique, as they are interconnected by focal adhesions known as "tight junctions", resulting in a highly selective barrier, the blood-brain barrier (BBB). This constitutes a highly specialized endothelial membrane lining cerebral microvessels with the astrocyte end-feet and pericytes [121]. BBB effectively regulates the passive exchange of solutes, transporter-mediated substances (e.g., glucose, amino acids, ions), signaling molecules, and the trafficking of macromolecules (e.g., proteins, peptides) between the blood and the brain [122]. It also regulates the entry of leukocytes and plasma components into the brain and ensures the exclusion of neurotoxic molecules [123-125]. The brain takes about $20 \%$ of the overall glucose and oxygen of the body, and brain microvessels are responsible for the delivery of both substrates to brain parenchyma. Therefore, a link between cerebrovascular alterations and neurodegeneration seems plausible [126,127]. Vast bibliography points out the interrelationship between cerebrovascular tissue and neurodegeneration, as well as confirms the age-dependent deterioration of the BBB during normal aging in the hippocampus, the brain region that is responsible for learning and memory, but faster degradation in patients with mild cognitive impairment (MCI) compared with neurologically intact controls [128-131].

At the functional level, the BBB is integrated into the neurovascular unit (NVU), composed of glial cells (astrocytes and microglia) and brain vascular cells (pericytes, endothelial cells, and vascular smooth muscle cells). NVU acts as a complex tissue with all its cells communicating with each other by secreting molecular factors named angioneurins. This communication allows the regulation of BBB integrity, angiogenesis, neuroprotection, vascular perfusion, and synaptic plasticity, thus ensuring the correct development, maintenance, and function of the unit in a healthy brain [132-135]. On the other hand, the $\mathrm{BBB} / \mathrm{NVU}$ dysfunction induces inadequate nutrient supply, accumulation of toxins in the brain, or altered secretion of proteins by NVU cells, which induce inflammation, oxidative stress, and neuronal damage. Dysfunction of the NVU is related to several CNS pathologies, 
such as ischemic and hemorrhagic stroke, tauopathies, MS, diabetic retinopathy, and HIV-1 infection [136-138].

Cerebrovascular inflammation is underlying during the progression of different CNS disorders, including $\mathrm{AD}$, stroke, traumatic brain injury, etc. Under normal physiological conditions, the BBB prevents adhesion molecules trafficking into the brain, however under pathophysiological conditions, the BBB integrity is impaired and different adhesion molecules, such as chemokines, selectins, and vascular cell adhesion molecules (CAMs), enter the CNS and pathologically enhance neuroinflammation $[139,140]$.

\subsection{Stroke}

The concept of stroke involves a heterogeneous group of processes. Ischemic stroke is caused by the obstruction of cerebral vessels and is the most common type of stroke, accounting for about $85 \%$ of the total. On the other hand, sudden bleeding in the brain induces a hemorrhagic stroke, accounting for the remaining cases [141]. Hemorrhagic stroke is due to bleeding into the brain by the rupture of a blood vessel, and it can be subdivided, depending on the localization of the blood vessels broken, into subarachnoid hemorrhage (SAH) and intracerebral hemorrhage (ICH). In SAH, the bleeding is into the subarachnoid space, while in $\mathrm{ICH}$, the bleeding is into the brain parenchyma. Hemorrhagic stroke is associated with severe morbidity and high mortality, and it is related to worse outcomes, such as deterioration of consciousness and neurological dysfunction.

Ischemic stroke results in a sudden loss of oxygen and glucose to the brain tissue, leading to neuronal cell death and severe brain damage. It involves multiple processes, such as energy failure, alteration of the ion homeostasis, increased intracellular calcium levels, excitotoxicity, free-radicals toxicity, arachidonic acid generation, cytokine cytotoxicity, the BBB disruption, infiltration of leukocytes, inflammation, glial cells activation, and apoptosis, among others [142]. Meanwhile, the lack of energy supply leads to mitochondrial dysfunction and oxidative and nitrosative stress. Postischemic inflammation brings further damage to brain cells and tissues during reperfusion. These events aggravate the initial injury and ultimately lead to the death of endothelial cells, pericytes, glial cells, and neurons composing the NVU [143,144].

Oxidative stress significantly contributes to tissue injury in acute ischemic stroke. During ischemia, damaged electron transportation generates excessive superoxide $\left(\mathrm{O}_{2}{ }^{-}\right)$, which facilitates the generation of other free radicals, such as $\mathrm{H}_{2} \mathrm{O}_{2}$ and hydroxyl radical (OH.). These reactive free radicals (ROS) further inhibit the mitochondrial electron transport, leading to even more ROS production $[145,146]$. Reperfusion also induces the production of $\mathrm{O}_{2}{ }^{-}$, nitric oxide (NO), and peroxynitrite. These free radicals are not only able to directly damage lipids, proteins, and nucleic acids to induce cell death but also activate MMPs to degrade collagen and laminins, which leads to vascular wall disruption and increased BBB permeability [142]. By activating the synthesis of transcription factors (e.g., NF-kB, hypoxia-inducible factor 1 (HIF-1), interferon regulatory factor 1 (IRF1), and signal transducer and activator of transcription 3 (STAT3)), oxidative stress is also able to induce numerous proinflammatory genes' expression (e.g., ICAM-1, VCAM-1, E-selectin, and $P$-selectin). As cerebral levels of antioxidant enzymes and substances are not high enough, oxidative stress is relatively more harmful to the brain than other organs [143].

Inflammation further exacerbates stroke-induced tissue injury. Different types of cells, extracellular receptors, and inflammatory mediators participate in the inflammatory response after stroke. Inflammatory cells, such as microglia and astrocytes, participate in post-ischemic tissue remodeling. Increasing evidence shows that cerebral ischemia can activate microglia and astrocytes, which can release proinflammatory cytokines and chemokines, such as TNF- $\alpha$, IL-1 $\beta$, interleukin- 6 (IL-6), and other cytotoxic molecules (e.g., NO and ROS) [147-149]. Moreover, ischemic stroke can cause the penetration of neutrophils and monocytes from the blood to the brain. Neutrophils are the earliest upregulated leukocyte subtype in the ischemic cerebral parenchyma [144], which triggers 
tissue damage by releasing ROS, proteases, and cytokines. Lymphocytes also participate in the inflammatory response after stroke and contribute to ischemia-induced damage [150].

CAMs facilitate leukocyte infiltration into the brain. During the inflammation process of an ischemic stroke, three classes of CAMs are activated: selectins, integrins, and immunoglobulins. During the early stage of ischemia, enhanced selectins, such as P-selectin and E-selectin, mediate leukocyte rolling and recruitment during inflammation [151]. Similarly, within hours after the onset of stroke, immunoglobulins, such as ICAM-1, can also be stimulated by cytokines secreted by microglia and astrocytes, among others [152]. In this context, soluble ICAM-1 (sICAM-1) has been proposed as an indicator for the severity of the stroke, as it is increased in acute ischemic stroke patients, and its expression level is significantly higher in patients who died than those who survived [153].

\subsection{Alzheimer's Disease and Cerebral Amyloid Angiopathy}

$\mathrm{AD}$ is the most common cause of dementia worldwide. Aging is its principal risk factor, together with others, including smoking, obesity, head trauma, previous depression, female gender, positive family history, and several other conditions involving vascularassociated pathologies as diabetes mellitus, hypercholesterolemia, hypertension, atherosclerosis, coronary heart disease, and stroke $[154,155]$. AD can be originated by familial genetic alterations or sporadically, constituting a heterogeneous disorder. Several mutations have been described in the familial $\mathrm{AD}$, accounting for those in the amyloid precursor protein (APP) and in presenilins 1 and 21 (PSEN1 and PSEN2) for most cases of the disease of this type $[156,157]$. However, the inheritance of the apolipoprotein $\mathrm{E}(\mathrm{apoE}) \varepsilon 4$ allele is the main genetic risk factor in sporadic AD [158,159], together with aging and other environmental factors.

$\mathrm{AD}$ is a progressive and neurodegenerative disease. Neuropathologically, the intracellular accumulation of hyperphosphorylated tau protein as neurofibrillary tangles and neuropil threads, together with the extracellular accumulation of amyloid- $\beta(A \beta)$ in the core of the neuritic plaques, are considered the two molecular and morphological signatures of $\mathrm{AD}$. $\mathrm{AD}$ is also associated with microvascular dysfunction, neurovascular disintegration, defective BBB function and other vascular factors [124], which may contribute to the disease progression [160].

Although still under debate, different evidence supports the idea that $\mathrm{A} \beta$ deposition is the central event in $\mathrm{AD}$ pathogenesis, which latterly induces the formation of neurofibrillary tangles, cell injury, vascular damage, and ultimately dementia [161]. In the amyloidogenic pathway, $\beta$ - and $\gamma$-secretases sequentially cleavage APP to generate A $\beta$ peptides [162-165]. According to the amyloid hypothesis on the cause of AD, the initiating event of the pathological process is the imbalance between the clearance and production of $A \beta$. Subsequently, A $\beta$ peptides over-accumulated at the extracellular level lead to neuronal degeneration and dementia [166].

In this regard, there have been described several molecular pathways responsible for the $A \beta$ clearance, being the most relevant the proteolytic degradation by extracellular proteases, such as insulin-degrading enzyme (IDE), neprilysin (NEP), and endothelinconverting enzyme (ECE) [167], and through the perivascular clearance, which comprises perivascular drainage and glymphatic pathways [168]. Another mechanism for the A $\beta$ clearing from the brain relies on the balance between the efflux and influx of $A \beta$ across the BBB [169]. In this regard, two receptors are responsible for the $A \beta$ transportation: the low-density lipoprotein receptor protein-1 (LRP-1) transports $A \beta$ from the brain to blood [170], while the receptor for advanced glycation end products (RAGE) [171] does it from blood to the brain.

Besides the two main pathological hallmarks, extraneuronal $A \beta$ plaques and neurofibrillary tangles, $\mathrm{AD}$ presents other traits, such as cerebral amyloid angiopathy (CAA) and inflammation. CAA is related to the accumulation of $A \beta$ in the walls of arteries, arterioles, capillaries, and veins of the leptomeningeal and cortical regions [172,173]. In CAA, A $\beta$ accumulates in cerebral blood vessels replacing smooth muscle cells and inducing vascular 
degeneration compromising the functionality and integrity of vessels and contributing to the BBB disruption [125].

In fact, $\mathrm{CAA}$ and $\mathrm{AD}$ pathology frequently co-occur, presumably because of the accumulation of $A \beta$ in the brain [174]. However, independently from $A D$, the risk of symptomatic lobar ICH and microscopic cortical infarcts is the most relevant clinical consequence of CAA [175]. CAA patients also present cognitive impairment, lower perceptual speed and episodic memory impairment, separately from the effect of AD [176]. CAA is a sporadic disease associated with age, although familial CAA cases are reported as a consequence of mutations in the APP gene located within or just outside the A $\beta$ coding region [174]. One of these mutations, for instance, causes the autosomal dominant disorder of Dutch-type hereditary CAA (also known as hereditary cerebral hemorrhage with amyloidosis (HCHWA)-Dutch type), which is clinically characterized by early-onset recurrent hemorrhagic strokes and dementia [177]. Nevertheless, the crosstalk between CAA and AD seems a clear example of the interactive effects of neurodegenerative and cerebrovascular diseases on cognition, which are likely a consequence of brain injuries caused by each process [174].

Wide bibliography emphasizes that vascular defects contribute to the onset and progression of neuronal degeneration and death in $\mathrm{AD}$ [178]. In this regard, the two-hit vascular hypothesis of $\mathrm{AD}$ incorporates a pathogenic vascular component to the excessive $\mathrm{A} \beta$ accumulation as initial events in the AD onset [132]. According to this hypothesis, vascular damage would impair the $A \beta$ clearance, which would accumulate in cerebral vessels and parenchyma to generate toxicity $[124,179]$. This vascular damage would be induced mainly but not exclusively by cerebral hypoperfusion, NVU dysfunction or BBB disruption, for example, by CAA. Studies reinforcing this hypothesis have demonstrated that vascular abnormalities occur before changes in $A \beta$ deposition, metabolic dysregulation, and functional impairment [180]. Hypoperfusion is detected at preclinical AD stages [181], and animal models of bilateral common carotid artery occlusion recapitulate AD pathology, including $A \beta$ accumulation [182]. Several studies have observed deficiencies in the neurovascular response to various stimuli in MCI or early-stage AD, evidencing an NVU dysfunction, as recapitulated by Solis et al. [160]. In addition, increased BBB permeability is found in $\mathrm{MCI}$ and early AD patients, correlating with increased BBB leakage [128,183].

At the molecular level, mitochondrial function declines with aging, in parallel to enhanced production of intracellular oxidative agents, including ROS, and the expression of nitric oxide synthase (NOS). The ROS and the reactive nitrogen species jointly contribute to the malfunction of the BBB and injury to the cerebral parenchymal cells [184].

In addition, inflammatory factors are elevated in microvessels in $\mathrm{AD} \mathrm{[185],} \mathrm{and} \mathrm{A} \beta$ is also able to induce the inflammatory cascade in human endothelial cells [186]. Cerebral endothelial activation inducing the expression of interleukins (IL-1 $\beta$, IL-6, IL-8), vascular endothelial growth factor (VEGF), TNF- $\alpha$, and MMPs, among others, occurs in AD altering brain homeostasis $[139,187]$. Elevated endothelial markers, such as E-selectin or VCAM-1, have been detected in the plasma of older subjects affected by late-onset $\mathrm{AD}$ and vascular dementia [139,188]. Moreover, activated microglia contributes to neuroinflammation and is associated with senile plaques in $\mathrm{AD}$ [189]. The presence of $\mathrm{A} \beta$ peptide in senile plaques of $\mathrm{AD}$ patients can also stimulate the secretion of proinflammatory cytokines and the complement system [190]. However, it also has been described that brain myeloid cells contribute to the $\mathrm{A} \beta$ removal through phagocytosis and that stimulation of the immune response in the CNS ameliorates A $\beta$ deposition [191]. Taken together all these results, it can be concluded that $\mathrm{AD}$ can be correlated with factors, such as inflammation, besides $\mathrm{A} \beta$ deposition and neurofibrillary tangle formation [192].

\section{SSAO/VAP-1 and Cerebrovascular Dysfunction}

\subsection{SSAO/VAP-1 in Stroke}

To date, increasing evidence implicates that SSAO/VAP-1 may play an important role in stroke. In humans, several studies demonstrated that the plasmatic SSAO/VAP-1 is 
altered in the stroke condition, as listed in Table 4. In ischemic stroke, it has been reported that serum SSAO/VAP-1 protein increases in the acute phase $(<6 \mathrm{~h})$, while levels of the membrane-bound protein in the ipsilateral hemisphere decrease [193]. Other authors found a small increase in SSAO activity in plasma $24 \mathrm{~h}$ after ischemia but more significant and from $1 \mathrm{~h}$ after symptoms onset when patients developed a hemorrhagic transformation (HT) [92]. Interestingly, the levels of SSAO activity in plasma predict the adverse neurological outcome in ischemic stroke patients and also represent a robust predictor of the appearance of parenchymal hemorrhages after the treatment with tissue plasminogen activator (tPA) in these patients [92]. In this study, an increased SSAO activity was observed in the ipsilateral hemisphere, contrary to Airas et al. 2008 [193]. Differences at this level may be due to different ways to measure the protein, such as immunohistochemical approaches or enzymatic activity determination, or by the pathological condition itself. In this regard, the presence of HT may lead to massive infiltration of plasma content into the parenchyma, including SSAO/VAP-1, which may account for this increased activity in the ipsilateral hemisphere, as found by Hernandez-Guillamon et al. 2010, but may not be present in ischemic conditions without HT. Other authors had found no differences in plasma SSAO activity after ischemic stroke when samples were obtained more than $24 \mathrm{~h}$ after the onset of symptoms [93]. In this regard, the time of plasma obtention after the onset of symptoms may be crucial to detect differences, as plasma SSAO activity has been reported to decrease after the acute phase [92] or weeks after stroke [94]. Even so, in acute ICH, the increased plasma SSAO activity predicts neurological outcome, suggesting a possible contribution of the soluble protein in the secondary brain damage after the initial bleeding. Remarkably, patients clinically diagnosed as possible or probable CAA cases presented higher plasma SSAO/VAP-1 activity than patients who showed a hypertensive-related ICH [95]. On the other hand, serum SSAO activity levels are also associated with the appearance of cerebral microbleeds in MS [194].

Interestingly, the SSAO enzymatic inhibition in several embolic stroke models performed in rats diminishes the CAMs expression, downregulating the inflammatory reaction, the leukocyte adhesion and extravasation, decreasing the infarct volume, and recovering the neurological outcome $[67,68,92,195,196]$, even in delayed cerebral ischemia $[67,68,92,195,196]$. Analogous anti-inflammatory activity and mitigated damage are found in animal models with suppressed SSAO activity or deficient in the SSAO/VAP-1 protein subjected to ischemiareperfusion treatment in the lung [195] and heart [196], and the SSAO/VAP-1 inhibition is proposed as a novel therapy in ischemic acute kidney injury [65].

SSAO activity is able to upregulate the expression of other CAMs, such as E- and P-selectins, ICAM, or VCAM $[63,197]$. In addition, a possible role of soluble SSAO/VAP-1 has been suggested to spread the inflammatory signal from the ipsilateral side of the ischemic brain to the contralateral side [198]. These facts may reinforce the benefits of SSAO/VAP-1 inhibition on inflammation control under a stroke condition.

Moreover, using an in vitro experimental model of oxygen-glucose deprivation (OGD), Sun et al. described the role of SSAO/VAP-1 present in endothelial cells during ischemic stroke, which was consistent with results obtained in animal models. Different OGD and reoxygenation conditions were analyzed, and SSAO/VAP-1 presence increased the susceptibility of endothelial cells to the OGD insult. Under these conditions, the oxidation of its substrate through its enzymatic activity boosted the resulting damage on vascular cells, with the activation of caspases 3 and 8 during the cell death process. OGD also constituted a spur for the release of soluble SSAO/VAP-1, which was found to be mediated in part by MMP-2-dependent shedding. On the other hand, short times of OGD stimulated SSAO/VAP-1-dependent leukocyte binding on endothelium, a function that partially depends on its enzymatic activity [199].

Besides the beneficial effects of blocking leukocyte adhesion in stroke conditions, the inhibition of SSAO/VAP- 1 activity also prevents the generation of $\mathrm{H}_{2} \mathrm{O}_{2}$, aldehydes and ammonia from its enzymatic catalyzation, which could contribute to oxidative stress in acute ischemic stroke when overproduced. In this regard, it has been reported that 
both the soluble [200] and the membrane-bound SSAO/VAP-1 could induce apoptosis in vascular cells through its oxidative metabolites [86], and this is enhanced under OGD conditions [199]. As brain cells are more sensitive to oxidative stress given their lack of antioxidants, good maintenance of the BBB tightness is crucial for preserving neuronal function. In this regard, the SSAO/VAP-1 inhibition could be beneficial in preserving the $\mathrm{BBB}$ by reducing the uncontrolled inflammation and maintaining the function of NVU after stroke.

\subsection{SSAO/VAP-1 in Alzheimer's Disease}

As previously reported, SSAO/VAP-1 is expressed in vascularized tissues, including the brain $[41,45-47,201]$. The presence of SSAO/VAP- 1 enzyme has also been determined in the brains of AD patients, as summarized in Table 4, and SSAO/VAP-1 immunoreactivity appeared restricted to meningeal and parenchymal blood vessels in the brain and markedly and selectively increased SSAO/VAP-1 immunoreactivity was observed to associate with vascular $A \beta$ deposits in patients with AD. Moreover, augmented SSAO immunoreactivity appeared associated with elevated $\mathrm{Cu} / \mathrm{Zn}$ superoxide dismutase 1 expression in abnormal blood vessels of diseased brains [96]. In parallel, circulating SSAO/VAP-1 was also assessed in the plasma of patients with sporadic AD. A clear rise in plasma SSAO activity was found in $\mathrm{AD}$ patients at moderate-severe and severe stages of the disease, compared to healthy controls [97]. No alteration of the enzyme was observed in AD patients with mild or moderate dementia compared with controls. Other authors have corroborated the plasma SSAO/VAP-1 increase in AD as well as in post-stroke dementia patients, negatively correlating with mini-mental state examination (MMSE) scores [98]. The elevation in plasmatic SSAO activity could be a consequence of its shedding from membrane-bound SSAO/VAP-1, particularly when the enzyme is overexpressed in AD [96]. Remarkably, plasma SSAO/VAP-1 levels did not correlate with A $\beta$ in plasma samples [97]. Altogether, these results suggested that an elevated plasmatic SSAO activity could contribute to oxidative stress and vascular damage in advanced AD.

On the other hand, numerous studies have exposed that many physiopathological alterations are shared features between $\mathrm{AD}$ and diabetes mellitus (DM), including elevated cholesterol levels, aging-related processes, metabolic disorders, glycogen synthase kinase-3 elevated activity, aggregation of $\mathrm{A} \beta$, association with cardiovascular diseases, increased oxidative stress, and inflammation response among others [99-102]. SSAO activity in the blood plasma of diabetic patients is also elevated [103]. Moreover, classic pathological signatures observed in $\mathrm{AD}$ are more prominent in diabetic patients, and $\mathrm{DM}$ constitutes a risk factor for AD [202,203]. In this context, the role of SSAO/VAP-1 was also assessed in human hippocampal vessels of non-demented $\mathrm{DM}, \mathrm{AD}$, and $\mathrm{AD}$ with diabetes mellitus (ADD) patients [204]. Results revealed enhanced accumulation of both SSAO/VAP-1 and $A \beta$ immunolabeling intensity in vessels from ADD compared with AD patients. Interestingly, injured vessels exhibiting elevated SSAO/VAP-1 staining also presented augmented oxidative damage indicators and glial activation. Globally, this study suggests that increased vascular SSAO/VAP-1 levels in the human hippocampus may contribute to the faster pathology evolution in patients with both diseases.

Besides DM, other cardiovascular and lifestyle-related risk factors are increasingly accepted to be relevant for the pathogenesis of AD [205]. In this context, plasma SSAO/VAP-1 is positively associated with coronary artery disease, and its expression is increased in atherosclerotic plaques in humans and in ApoE-deficient mice [206]. Moreover, SSAO inhibition reduces atheroma, decreases oxidative stress in Apo-E-deficient mice, and attenuates the expression of adhesion molecules, chemoattractant proteins, and proinflammatory cytokines in the aorta. Thus, together with DM, the SSAO/VAP-1 alteration in several AD risk factors suggests that it could be not only involved in $\mathrm{AD}$ progression but also in the AD onset.

The aldehydes generated from methylamine metabolism by SSAO/VAP-1 are involved in protein unfolding and generate protein cross-linkages into lysine residues [207,208]. 
Therefore, it is reasonable to hypothesize that these compounds may react with lysines of $A \beta$ to promote vascular aggregation of $A \beta$ in $A D$ patients. In this regard, the potential effects of these SSAO-generated endogenous aldehydes have been implicated in $\mathrm{A} \beta$ misfolding, oligomerization, and fibrillogenesis [209,210]. In fact, formaldehyde concentrations are elevated in senescence-accelerated mouse-prone 8 (SAMP8) mice, which correlates with cognitive dysfunction, and is associated with increased SSAO activity of these mice [211]. In addition, urine formaldehyde measurement has been proposed as a biomarker for $\mathrm{AD}$ and post-stroke dementia progression as, in parallel to plasma SSAO/VAP-1 content, it negatively correlates with MMSE scores [98]. These results suggest that increased SSAO/VAP-1 expression, as well as its circulating form, maybe a source of oxidative stress in the blood vessel wall in AD. Moreover, considering that SSAO/VAP-1 is overexpressed in cerebrovascular tissue of patients with CAA-AD, and its intrinsic enzymatic activity generates pro-aggregating metabolites, one can conclude that SSAO/VAP-1 may contribute to the vascular damage associated with $\operatorname{AD}[212,213]$.

Table 4. Alterations of SSAO/VAP-1 levels found in human ischemic stroke, intracerebral hemorrhage (ICH) and Alzheimer's disease (AD).

\begin{tabular}{|c|c|c|c|c|}
\hline Disorder & Tissue Analyzed & $\begin{array}{c}\text { Phase of the } \\
\text { Pathology }\end{array}$ & SSAO/VAP-1 Alteration & Reference \\
\hline \multirow{7}{*}{ Ischemic stroke } & Serum & $<6 \mathrm{~h}$ (acute phase) & Increase & [193] \\
\hline & Plasma & $24 \mathrm{~h}$ after stroke & Increase vs. $1 \mathrm{~h}$ & [92] \\
\hline & Plasma & $1 \mathrm{~h}$ after $\mathrm{HT}$ & Increase & [92] \\
\hline & Serum & $>24 \mathrm{~h}$ after stroke & No change & [93] \\
\hline & Plasma & weeks after & Decrease & [94] \\
\hline & Ipsilateral brain & - & Decrease & [193] \\
\hline & Ipsilateral brain & - & Increase & [92] \\
\hline \multirow{2}{*}{$\begin{array}{l}\text { Hemorrhagic stroke } \\
\text { (ICH) }\end{array}$} & Plasma & $3-4 \mathrm{~h}$ after ICH & Increase & [95] \\
\hline & Contralateral brain & - & Increase & [95] \\
\hline \multirow{6}{*}{$\mathrm{AD}$} & Plasma & moderate-severe & Increase & [97] \\
\hline & Plasma & - & Increase & [98] \\
\hline & Brain vessels & - & Increase & [96] \\
\hline & Hippocampus & - & Increase & [98] \\
\hline & Brain vessels & - & Increase & [204] \\
\hline & Brain vessels & - & Increase & [212] \\
\hline
\end{tabular}

As shown in Figure 1, the abilities of SSAO metabolic products (e.g., $\mathrm{H}_{2} \mathrm{O}_{2}$, ammonia, and aldehydes) to generate oxidative stress, to enhance the AGEs generation, to promote the $\mathrm{A} \beta$ aggregation, and to induce apoptosis, reinforce the role of SSAO/VAP-1 in CAAAD-related vascular pathology.

On the other hand, other functions attributed to endothelial SSAO/VAP-1 also may play a role in promoting or aggravating the pathology of $\mathrm{AD}$, including those related to granulocytes binding and leukocyte trafficking into tissues. In this regard, different peripheral inflammatory cells have been detected in brains from AD and animal models: monocytes, lymphocytes and neutrophils [214]. The adhesion function of SSAO/VAP-1 is particularly active for neutrophils. Neutrophils infiltrate the brain parenchyma in AD and migrate towards $\mathrm{A} \beta$ deposits in the experimental mouse model [215]. However, this neutrophil infiltration resulted in an exacerbation of microgliosis and behavioral deficits in an experimental AD model [216]. More recently, it has been demonstrated that neutrophil adhesion in brain capillaries may impair cognitive functions [217]. These and other studies performed in mouse AD models indicate that neutrophils may contribute to the initial stages of the disease [214,218]. Although the specific participation of SSAO/VAP-1 has not been assessed in these models, it is reasonable to believe that the potential inhibition of leukocyte trafficking may be beneficial in AD. Thus, the regulation of VAP-1 may also be considered as a strategy to address this aspect associated with the pathology. 
SSAO catalytic activity $\mathrm{RCH}_{2} \mathrm{NH}_{2}+\mathrm{O}_{2}+\mathrm{H}_{2} \mathrm{O} \stackrel{\text { SSAO }}{\longrightarrow} \mathrm{RCHO}+\mathrm{NH}_{3}+\mathrm{H}_{2} \mathrm{O}_{2}$

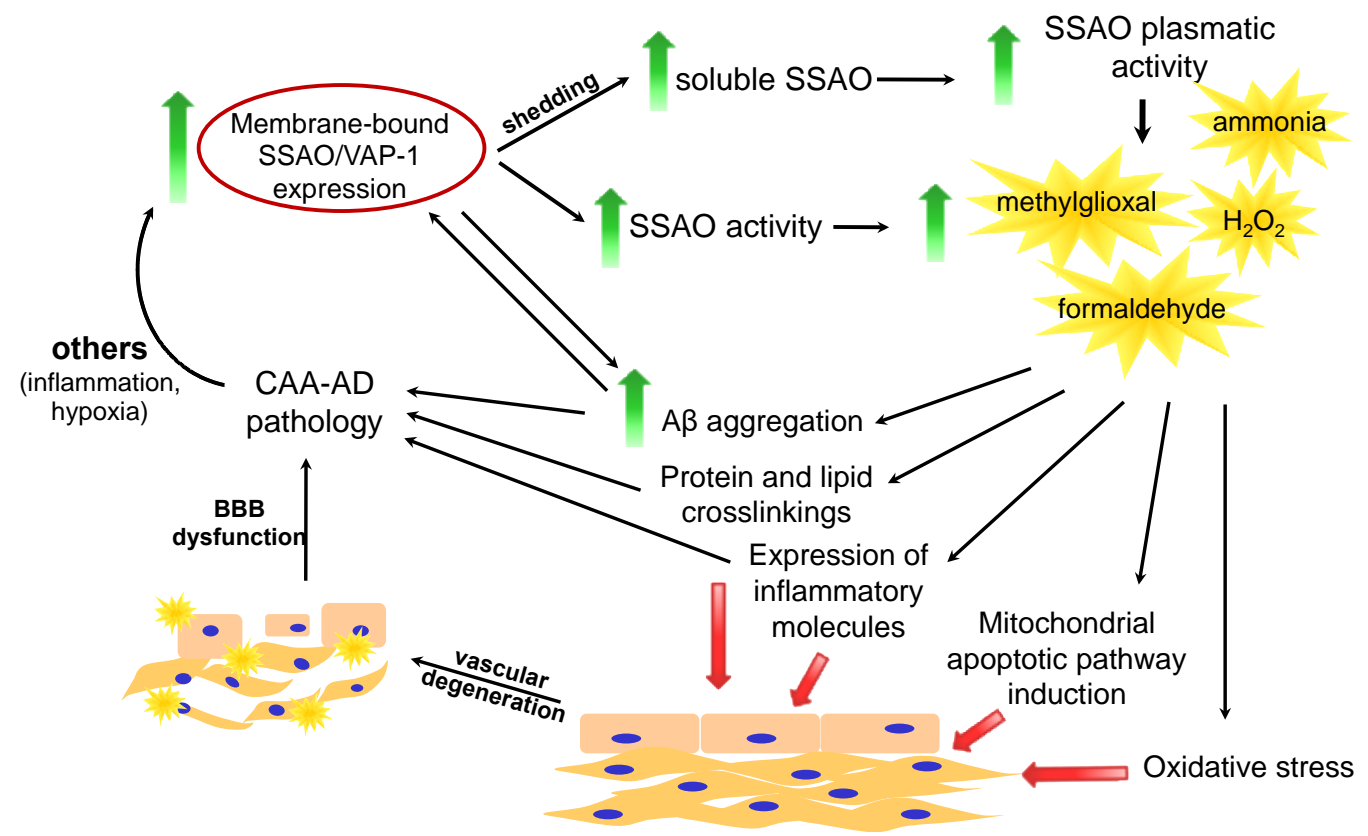

Figure 1. Summary of the pathogenic mechanisms of SSAO/VAP-1 in exacerbating the progress of cerebral amyloid angiopathy (CAA)-AD. Through the generation of toxic metabolites from SSAO activity (ammonia, methylgioxal, formaldehyde, and $\mathrm{H}_{2} \mathrm{O}_{2}$ ), SSAO/VAP-1 induces the vascular degeneration on both endothelial and smooth muscle cells through several mechanisms: (i) oxidative stress, (ii) induction of apoptosis through the mitochondrial pathway, (iii) induction of the expression of pro-inflammatory molecules (selectins, VCAM, ICAM ... ), (iv) induction of protein and lipid crosslinking, and (v) increase in $\mathrm{A} \beta$ aggregation. The resulting vascular degeneration, together with the protein and lipid crosslinkage and the $A \beta$ aggregation contribute to the vascular degeneration and the CAA pathology, and these generate a positive feedback loop reinforcing SSAO/VAP-1 overexpression. A $\beta$ aggregation itself also contributes to the SSAO/VAP-1 increase.

From this background, elucidating whether vascular SSAO/VAP-1 modulation is a consequence, or a cause of specific pathologic processes seems a question that needs to be solved. However, the study of this enzyme is difficult since the primary culture of SSAO/VAP-1-positive cells gradually loses its expression, and immortalized cell lines do not display activity or expression of SSAO [34,48]. In this concern, newly developed vascular cell lines stably expressing the human SSAO/VAP-1 have been established [219-221]. The transfected protein is essentially expressed as a dimer in the vascular cells membrane, and specifically, localize in the lipid rafts of these cells. The protein levels and enzymatic activity, and kinetic parameters of the enzyme in these cells are similar to those detected in vivo by the same cell types. These new SSAO/VAP-1-expressing endothelial cell lines (HUVEC, human umbilical vein endothelial cells, and hCMEC/D3, human cerebral microvascular endothelial cells) are also able to mediate leukocyte adhesion, a known function of SSAO/VAP-1 in endothelium under inflammatory conditions that are not observed in smooth muscle cells [222]. Thus, these new cell lines constitute suitable experimental tools for studying new functions of SSAO/VAP-1, as well as to elucidate its role in pathological processes or to evaluate potential molecules that could modify its activity for therapeutic purposes [222].

To reveal the nature of the SSAO/VAP-1 relationship with the AD pathology, cell lines stably expressing human SSAO/VAP- 1 were treated with different $A \beta$ forms to simulate the CAA conditions in vitro [220]. The vasculotropic Dutch-mutated $A \beta 1-40\left(A \beta_{1-40} D\right)$ peptide, which accumulates in vessels of the Dutch-type hereditary CAA brain, was used to reproduce the pathology in vitro. It was found that the treatment with $A \beta_{1-40} \mathrm{D}$ increased the vascular SSAO/VAP-1-dependent toxicity, which was correlated by a rise of 
SSAO/VAP-1 protein in the membrane of endothelial cells. Moreover, SSAO/VAP-1 enhanced the deposition of $A \beta$ on vascular cells by both activity-dependent and -independent mechanisms. Taken together, these data suggest that $A \beta$ itself can be one of the elements stimulating the SSAO/VAP-1 elevation in AD, augmenting its toxic action, and inducing the vascular dysfunction and, in turn, that SSAO/VAP- 1 can stimulate $\mathrm{A} \beta$ deposition on the vascular walls, thereby contributing to the CAA-AD progression.

As previously mentioned, the function and structure of both NVU and BBB are abundantly compromised in several neurological diseases, such as stroke and [223]. In this context, it is necessary to study the neurovascular crosstalk and alterations to better comprehend the molecular base of AD [123]. Therefore, a new in vitro model of NVU was used to assess the possible contribution of vascular SSAO/VAP-1 overexpression to the BBB dysfunction through its role on endothelial activation, the modification of angioneurins release and the alteration of the NVU communication [224]. As human umbilical venous endothelial cells, HUVECs are different from those present in the endothelium of the BBB. To better mimic the NVU model, the cell line hCMEC/D3 [225] was stably transfected with hSSAO/VAP-1 [221]. With this model, it was interesting to decipher the role of SSAO/VAP1 in endothelial activation, the angioneurins release, the BBB permeability, the BBB function alteration, and the A $\beta$ deposition. Using the hSSAO/VAP-1-expressing hCMEC/D3 cells, co-cultured with mixed mouse neuron-glia primary cultures as an experimental model of $\mathrm{NVU}$, it was observed that SSAO/VAP-1 induced the endothelial activation by modifying the release of proinflammatory and pro-angiogenic angioneurins IL-6, IL-8, and VEGF. In parallel, the alteration of the BBB structure was also exhibited a decreased level of tight-junction proteins, such as zona ocludens- 1 and claudin-5. The activation of signaling pathways by the products of SSAO catalytic activity or the structural modifications induced by only the presence of this enzyme could be the molecular mechanisms responsible for regulating these phenotypic changes. An increasing permeability and leukocyte adhesion, as well as an augmentation of $A \beta$ deposition, were also observed by both enzymatic activity-dependent and independent mechanisms [224]. These results revealed that the expression of SSAO/VAP-1 in human brain microvessels induces an endothelial activation status towards a proinflammatory phenotype, accompanied by BBB leakage and leukocyte adhesion. In addition, the proinflammatory molecules released by the enzymatic activityindependent mechanisms could affect the surrounding microenvironment, the neighboring cells, and thus the NVU. Furthermore, the SSAO activity in enhancing leukocyte adhesion and $\mathrm{A} \beta$ deposition on endothelial cells suggests SSAO/VAP-1 inhibition, a promising strategy to bring beneficial effects for the treatment of AD [224].

\section{Can SSAO/VAP-1 Be a Link between Stroke and AD?}

\subsection{Stroke and the Risk for $A D$}

Mounting evidence suggests that disorders affecting the vascular system, as can be cerebrovascular diseases, including stroke, play a significant part in the development and progress of neurological diseases like AD in the elderly $[123,139,226,227]$. The existence of a strong link between vascular damage and $\mathrm{AD}$ is evidenced by a high percentage of patients who have suffered strokes and subsequently develop AD [228,229]. In this regard, several reports revealed that brain stroke/ischemia significantly rises the occurrence of $\mathrm{AD}[226,230,231]$. This risk is even more elevated in cases where other vascular risk factors, for example, atherosclerosis, coexist with stroke [226]. Several mechanisms may contribute to this fate, as recently reviewed by Goulay et al. [227].

Both hypoxia and ischemic injury induce upregulation of $A \beta$ generation, confirming the link between stroke and AD [228,229]. Evidence also indicates that increased APP accumulation is present at areas of ischemic brain damage in models of middle cerebral artery occlusion (MCAO) or focal cerebral ischemia. Thus, the APP cleavage may be induced under ischemic conditions [230-237]. Moreover, hypoxia induces the increase of BACE- 1 expression and activity to increase the A $\beta$ generation. Prolonged hypoxia can also induce mitochondrial dysfunction, neuronal loss, and potential memory deficits, 
facilitating the pathogenesis of $\mathrm{AD}[238,239]$. Mechanistic studies reveal that both oxidative stress and HIF-1 are accountable for the elevated expression of beta-secretase 1 (BACE-1) at distinct phases after cerebral ischemia [240].

Besides increasing $A \beta$ generation, ischemic conditions can alter the $A \beta$ clearance by inducing downregulation of the levels of NEP and ECE- 1 in the brain, enzymes that are responsible for the degradation of $A \beta[241,242]$. In addition, several mechanisms can harm the BBB after hypoxia/ischemia insults, including altering the expression of major $A \beta$ clearance enzyme LRP-1 to impair the clearance of $A \beta$ from the brain [243]. Moreover, the expression of RAGE, another important protein in the BBB that transports $A \beta$ across $B B B$ to the brain, is upregulated in the brains of mice undergone an experimental stroke or systematic hypoxia, thus diminishing the $A \beta$ clearance from the brain [244]. On the other hand, it has been described that transient hypoxia damage can increase the hyperphosphorylation of tau in cortical neurons $[245,246]$.

Ischemic or hemorrhagic stroke frequently involves the breakdown of the BBB, and as a consequence, soluble plasmatic proteins reach brain parenchyma, triggering inflammation and subsequent neurodegeneration $[247,248]$. In addition, the excessive release of free radicals and oxidative environment generated as a result of stroke injury are well-known contributors to the development and progression of $\operatorname{AD}[249,250]$.

Among the common features between stroke and $\mathrm{AD}$, restricted brain perfusion, cerebrovasculature dysfunction, and inflammation are the most significant ones, which finally lead to neuronal injury and cognitive impairment [251]. All these data allow us to conclude that it exists a robust association between $\mathrm{AD}$ and cerebrovascular disease, and the injury effects of stroke, through numerous pathways, could facilitate neurodegeneration, worsen dementia, and the outcome of AD.

\subsection{AD and the Risk for Stroke}

Cerebral hypoperfusion, atherosclerosis, oxidative stress, and vascular $A \beta$ deposition around the cerebral vascular wall as CAA are alterations found in AD that can lead to an acute cerebrovascular functional failure by way of brain ischemia or hemorrhage [240]. CAA directly compromises cerebrovascular function, causing not only cerebral hypoperfusion, and therefore, chronic ischemia but also BBB disruption and micro-bleeds [252,253]. In fact, CAA is associated with hemorrhagic stroke [254], and symptomatic patients with CAA often present with lobar intraparenchymal hemorrhages [255].

At the molecular level, A $\beta$ presence decreases the expression of tight junction proteins in experimental models and in human samples, which is associated with BBB leakage $[256,257]$. Under these conditions, MMP-2 and MMP-9 are upregulated and degrade the cerebral basement membrane and lead to cerebral hemorrhage [258].

Inflammation acts as another important contributor to neurovascular dysfunction since the main source of vascular reactive oxygen species contributing to the $A \beta$-associated cerebral blood flow disturbances are perivascular macrophages reacting to vascular $A \beta$ [259]. Vascular A $\beta$ deposits promote the migration of monocytes across BBB [260], which generate oxidative stress and proinflammatory cytokines [261]. Clusters of activated microglia are also present around vascular $A \beta$ deposits [262]. These cells create an inflammatory response to release proinflammatory cytokines and oxidative stress mediators that induce the loss of BBB integrity by the disruption of tight junctions [263]. In addition, A $\beta$ deposition on vascular walls activates cell signaling pathways in endothelial and smooth muscle vascular cells that contribute to the BBB disruption, as apoptotic cell death pathways, generation of free radicals, and disruption of intracellular $\mathrm{Ca}^{2+}$ homeostasis [264]. These vascular cells are also able to release proinflammatory cytokines that are upregulated in $\mathrm{AD}$, contribute to the CAA progression and the subsequent development of hemorrhages. The specific mechanism of this vascular cells-mediated inflammatory response is not clearly defined, but it is thought to contribute to the BBB breakdown [265]. 


\subsection{SSAO/VAP-1 As a Possible Link between Stroke and AD}

SSAO/VAP-1, which is present in the cerebrovasculature, and particularly in the endothelial and smooth muscle cells, is a common factor involved in the pathogenesis of stroke and $\mathrm{AD}$, but may also be a possible link between both diseases, mediating the onset of one of them in patients affected by the other.

On one hand, evidence has exposed that SSAO/VAP-1 is abnormally elevated in the cerebrovascular tissue, colocalizing with $\mathrm{A} \beta$ deposits in $\mathrm{AD}$ patients $[96,206,214]$. There, SSAO/VAP-1 is able to promote aggregation of $A \beta$, vascular cell injury through its enzymatic activity, and lead to the BBB dysfunction $[211,215,222,228]$. In addition, in smooth muscle cells from brain meninges, excessive SSAO/VAP-1 activity would contribute to the $\mathrm{A} \beta$ aggregation and extracellular matrix cross-linkage, inducing the rigidity of the vessel and the final breakdown generating hemorrhage. The increased SSAO/VAP-1 present in blood plasma has already been associated with vessel wall breaking, for instance, in ischemic stroke patients undergoing HT [92]. Given these considerations, it is reasonable to deduce that under AD conditions, the alterations induced by SSAO/VAP-1 could easily drive to a vascular wall weakening and, therefore, to an increased risk of suffering a subsequent hemorrhagic stroke in the presence of $\mathrm{AD}$.

On the other hand, SSAO/VAP-1 participates in the inflammatory response in multiple models of stroke $[67,92,195]$, mediating leukocyte-endothelium adhesion and upregulating other CAMs $[63,199,266,267]$, augmenting the leukocyte adhesion cascade, and producing toxic and pro-aggregating products, such as $\mathrm{H}_{2} \mathrm{O}_{2}$ and formaldehyde [62]. These products are directly involved in the oxidative stress and $A \beta$ aggregation responsible for $A D$ pathology. Thus, the SSAO/VAP-1 alterations produced during a stroke may contribute to generating the conditions necessary for the $\mathrm{AD}$ onset in stroke patients: a high pro-oxidant, pro-aggregating and inflammatory environment. The increased plasma SSAO/VAP-1 presence described in post-stroke dementia patients [98] reinforces this hypothesis. Although more research should be done to establish the SSAO/VAP-1 alterations as a causative link between stroke and $\mathrm{AD}$, the evidence existing so far suggests that SSAO/VAP-1 could participate in the transition from stroke to $\mathrm{AD}$ or from $\mathrm{AD}$ to stroke.

\section{Therapeutic Approach to Stroke and AD by SSAO/VAP-1 Inhibition}

The vast bibliography on the association of SSAO/VAP-1 with DM, atherosclerosis, $\mathrm{AD}$, or stroke has suggested this enzyme as an important therapeutic target for these diseases [195]. Moreover, there is a wide consensus in describing AD pathogenesis as a multifaceted neurological disorder, which development and evolution may be prompted by several mechanisms embracing cholinergic dysfunction, oxidative stress and free radicals formation, disproportionate protein misfolding and aggregation, biometal dyshomeostasis, excitotoxicity, and neuroinflammation, in addition to disturbances in the monoaminergic and glutamatergic systems. Furthermore, the increase of BACE-1 induced by both hypoxia and ischemic damage enhances the $\mathrm{A} \beta$ generation, confirming the link between $\mathrm{AD}$ and stroke $[228,240]$.

Because modifications of the levels of plasmatic SSAO/VAP-1 humans have been associated with several pathological conditions such as ischemic stroke and AD [92,95,96,193], it would be interesting to design new molecules able to inhibit SSAO/VAP-1 and to interact with other molecular systems involved in $\mathrm{AD}$ and stroke, as a novel therapeutic option.

Drugs currently approved by the US Food and Drug Administration (FDA) drugs for the treatment of $\mathrm{AD}$-associated cognitive deficits are grounded on the cholinergic hypothesis of AD with limited therapeutic interest [268,269]. Given the limited effectivity of anticholinergic therapies as well as the multifactorial and extreme complexity of $\mathrm{AD}$ nature, several researchers have suggested a new idea, based on "one molecule, multiple targets," also known as the multi-target directed-ligand (MTDL) approach, which proposes the beneficial use of molecules with numerous pharmacological profiles that would allow them to interact with diverse molecular targets [266,270-273]. 
Regarding the new series of MTDL molecules designed to be used in AD therapy, it was interesting to analyze their effect on cerebral ischemia as well. A novel series of molecules grown on the hybridization of selected moieties from donepezil, propargylamine, and 8-hydroxyquinoline (DPH), were synthesized and pharmacologically assessed for the prevention of AD [267]. Among them, the DPH4 (Figure 2) resulted in being a good MAO$\mathrm{A}, \mathrm{MAO}-\mathrm{B}$, acetylcholinesterase (AChE), and butyrylcholinesterase (BuChE) inhibitor, and besides, DPH4 displayed robust biometal chelating properties against $\mathrm{Cu}^{2+}$ and $\mathrm{Fe}^{2+}$, good absorption, distribution, metabolism, excretion, and toxicity (ADMET) properties confirming its interesting properties to be used in AD therapy. In this context, the possible protective effect of DPH4 in cerebral ischemia was studied, as well.

\section{N-benzylpiperidine-Donepezil (AChE-inhbition)}

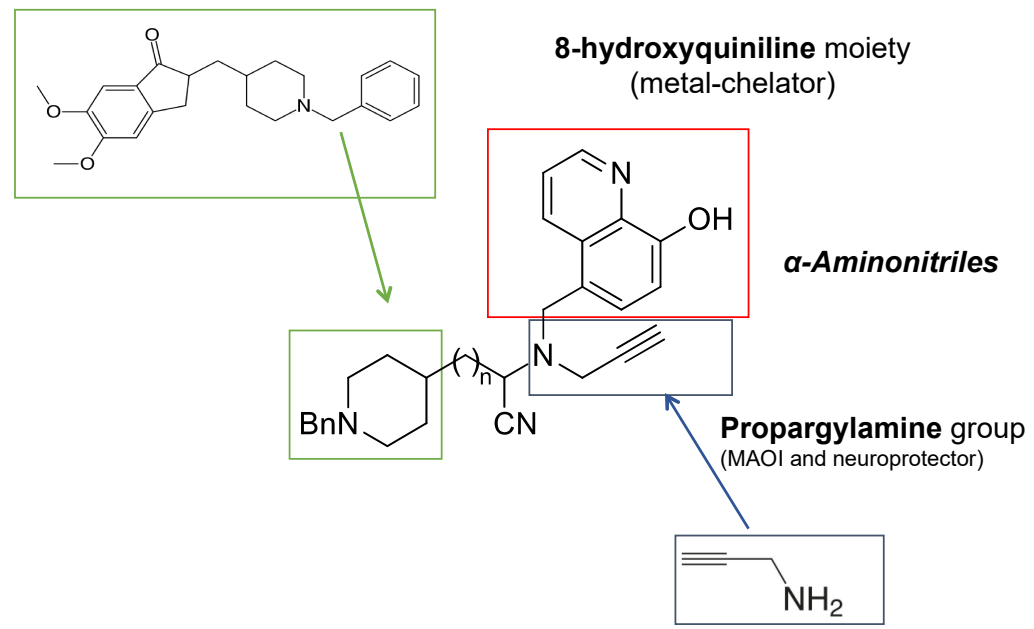

Figure 2. Structure of the multi-target directed-ligand (MTDL) donepezil-propargylamine-8hydroxyquinoline, DPH4 [221].

Using an experimental model of ischemic stroke, the cell viability of the human cerebral microvascular endothelial cells stably expressing the hSSAO/VAP-1 was assessed after OGD and reoxygenation in the presence of DPH4. Under these hypoxic conditions, a release of soluble SSAO/VAP-1 was observed, contributing to the vascular cell damage through its catalytic action. DPH4 pretreatment mediated a dose-dependent protective effect on hSSAO/VAP-1-expressing hCMEC/D3 cells in the presence of methylamine in both normoxic and OGD with reoxygenation conditions. The beneficial action of DPH4 was significant on inflammation also, as DPH4 significantly diminished the adhesion of leukocytes to the endothelium in the presence of methylamine, as a consequence of its inhibitory action on SSAO activity. To simulate a pre-existing $A D$ pathology, $A \beta_{1-40} \mathrm{D}$ treatment was introduced into this experimental model of ischemia. DPH4 showed a protective effect against the synergistic damaging effect induced by methylamine and $\mathrm{A} \beta_{1-40} \mathrm{D}$. These results not only confirmed the important role that SSAO/VAP-1 plays in enhancing endothelial cell death under ischemia but also suggest that DPH4, a new MTDL molecule containing donepezil, propargylamine, and 8-hydroxyquinoline, is able to protect brain endothelial cells under hypoxia through its inhibitory and anti-inflammatory activity on SSAO/VAP-1, and may be used for AD therapy [221].

Moreover, a new series of molecules, such as indole substituted hydrazides and hydrazines, were synthesized as potential MAO inhibitors in vitro [274,275], and have been analyzed of their multipotent inhibitory potency towards MAOs A and B, SSAO/VAP-1, $\mathrm{AChE}$ and BuChE. Among them, the hydrazine JL72 (3-(3-hydrazinylpropyl)-1H-indole) exhibited a potent, reversible inhibitory activity on MAO-A, which suggests its ability to restore serotoninergic neurotransmission. Moreover, it behaved as a moderate BuChE inhibitor and as a high-affinity inhibitor towards SSAO/VAP-1. The molecule JL-72 also 
showed significant anti-inflammatory activity in HUVEC hSSAO/VAP-1-expressing cells by measuring leukocyte adhesion on the endothelium. Taken together these results, JL-72 resulted in being a good candidate lead compound for the subsequent development of drugs targeting cerebrovascular and neurological diseases, such as stroke and AD [21].

The neuroprotective effect of statins has been widely reported in the therapy of neurodegenerative diseases such as Parkinson's disease, AD, and vascular dementia [276]. Regarding their beneficial effects observed in stroke, these effects have been described to be independent of their role in cholesterol reduction [277]. Two different animal models of stroke (embolic MCAO through the injection of a clot, eMCAO; and transient MCAO by introducing an intraluminal filament, tMCAO [278], and an in vitro model of stroke using human brain microvascular endothelial cells expressing SSAO/VAP-1 under OGD, were used to assess the possible involvement of SSAO/VAP-1 in the protective effect of simvastatin. In the animal model, the soluble SSAO/VAP-1 is released into the bloodstream after an ischemic stimulus, correlating with an increase in E-selectin, VCAM-1, and with the infarct volume. Simvastatin blocked soluble SSAO/VAP-1 release and prevented Eselectin and VCAM-1 overexpression, and also effectively blocked SSAO/VAP-1-mediated leukocyte adhesion. The attenuation of SSAO/VAP-1 release could be responsible for the beneficial effects of simvastatin observed in protecting against the proinflammatory effects of ischemia in these animal models. Similar results were also observed in cultured cell lines and, therefore, highlight the importance of the attenuation of SSAO/VAP-1-dependent inflammatory response in the process [198].

\section{Conclusions}

All these data allow us to conclude that a robust connection between cerebrovascular diseases and $\mathrm{AD}$ exists, and the adverse effects of the stroke condition, through multiple pathways, could enable the progression to neurodegeneration and the outcome of AD. On the other hand, AD could also facilitate the appearance of stroke and aggravate the outcome following strokes. Most interestingly, based on the data discussed above, SSAO/VAP-1 could be a common link between both pathologies. In this context, the design of new MTDL molecules being able to inhibit SSAO/VAP-1 activity and interact with the cholinergic and monoaminergic system could be a promising therapeutic approach for the treatment of both stroke and AD.

Author Contributions: Writing the original draft, M.U. and M.S.; review and editing, P.S.; review, M.H.-G.: Funding acquisition, M.H.-G. All authors have read and agreed to the published version of the manuscript.

Funding: This research received no external funding. The Neurovascular Research Laboratory is part of the INVICTUS+ network, ISCIII, Spain (RD16/0019/0021).

Institutional Review Board Statement: Not applicable.

Informed Consent Statement: Not applicable.

Data Availability Statement: Not applicable.

Conflicts of Interest: The authors declare no conflict of interest. The funders had no role in the design of the study, in the collection, analyses, or interpretation of data, in the writing of the manuscript, or in the decision to publish the results.

\section{Abbreviations}

$\mathrm{A} \beta \quad$ Amyloid- $\beta$

AChE Acetylcholinesterase

AD Alzheimer's disease

ADD AD with diabetes mellitus

ADMET Absorption, distribution, metabolism, excretion, and toxicity

AGEs Advanced glycation end products

AOs Amine oxidases 


\begin{tabular}{|c|c|}
\hline apoE & Apolipoprotein E \\
\hline APP & Amyloid precursor protein \\
\hline BACE-1 & Beta-secretase 1 \\
\hline BBB & Blood-brain barrier \\
\hline BuChE & Butyrylcholinesterase \\
\hline CAA & Cerebral amyloid angiopathy \\
\hline CAMs & Cell adhesion molecules \\
\hline CNS & Central nervous system \\
\hline $\mathrm{DAO}$ & Diamine oxidase \\
\hline $\mathrm{DM}$ & Diabetes mellitus \\
\hline DMBA & 7,12-dimethylbenz(alpha)anthracene \\
\hline EAE & Experimental autoimmune encephalomyelitis \\
\hline ECE & Endothelin-converting enzyme \\
\hline eMCAO & Embolic MCAO \\
\hline FAD & Flavin adenine dinucleotide \\
\hline FDA & Food and Drug Administration \\
\hline GLUT & Glucose transporters \\
\hline $\mathrm{H}_{2} \mathrm{O}_{2}$ & Hydrogen peroxide \\
\hline HCHWA & Hereditary cerebral hemorrhage with amyloidosis \\
\hline hCMEC/D3 & Human cerebral microvascular endothelial cells \\
\hline HEVs & High endothelial venules \\
\hline HIF-1 & Hypoxia-inducible factor 1 \\
\hline HT & Hemorrhagic transformation \\
\hline HUVEC & Human umbilical vein endothelial cells \\
\hline ICAM-1 & Intracellular adhesion molecule 1 \\
\hline $\mathrm{ICH}$ & Intracerebral hemorrhage \\
\hline IDE & Insulin-degrading enzyme \\
\hline IL-1 $\beta$ & Interleukin 1 beta \\
\hline IL-6 & Interleukin 6 \\
\hline IFN- $\gamma$ & Interferon- $\gamma$ \\
\hline IRF1 & Interferon regulatory factor 1 \\
\hline JL-72 & 3-(3-hydrazinylpropyl)-1H-indole \\
\hline JNK & c-Jun amino-terminal kinase \\
\hline LOX & Lysyl oxidase \\
\hline LPS & Lipopolysaccharide \\
\hline LRP-1 & Lipoprotein receptor protein-1 \\
\hline LTQ & Lysine tyrosyl quinone \\
\hline $\mathrm{MAO}$ & Monoamine oxidase \\
\hline MAPK & Mitogen-activated protein kinase \\
\hline MCAO & Middle cerebral artery occlusion \\
\hline MCI & Mild cognitive impairment \\
\hline MMPs & Matrix metalloproteinases \\
\hline MMSE & Mini-mental state examination \\
\hline MS & Multiple sclerosis \\
\hline MTDL & Multi-target directed-ligand \\
\hline NEP & Neprilysin \\
\hline $\mathrm{NO}$ & Nitric oxide \\
\hline NOS & Nitric oxide synthase \\
\hline NVU & Neurovascular unit \\
\hline $\mathrm{O}_{2}^{-}$ & Superoxide \\
\hline OGD & Oxygen-glucose deprivation \\
\hline $\mathrm{OH}$ & Hydroxyl radical \\
\hline $\mathrm{PAO}$ & Polyamine oxidase \\
\hline PLN & Peripheral lymph node \\
\hline PNAd & Peripheral lymph addressin \\
\hline PrAO & Primary amine oxidase \\
\hline PSEN & Presenilin \\
\hline RAGE & Receptor for advanced glycation end products \\
\hline ROS & Reactive free radicals \\
\hline SAH & Subarachnoid hemorrhage \\
\hline
\end{tabular}




$\begin{array}{ll}\text { SAMP8 } & \text { Senescence accelerated mouse-prone } 8 \\ \text { SSAO } & \text { Semicarbazide-sensitive amine oxidase } \\ \text { STAT3 } & \text { Signal transducer and activator of transcription } 3 \\ \text { tMCAO } & \text { Transient MCAO } \\ \text { TNF- } \alpha & \text { Tumor necrosis factor } \alpha \\ \text { tPA } & \text { Tissue plasminogen activator } \\ \text { TPQ } & \text { Topa-quinone } \\ \text { VAP-1 } & \text { Vascular adhesion protein-1 } \\ \text { VCAM-1 } & \text { Vascular cell adhesion protein 1 } \\ \text { VEGF } & \text { Vascular endothelial growth factor }\end{array}$

\section{References}

1. Gong, B.; Boor, P.J. The role of amine oxidases in xenobiotic metabolism. Expert Opin. Drug Metab. Toxicol. 2006, 2, 559-571. [CrossRef]

2. Johnston, J. Some observations upon a new inhibitor of monoamine oxidase in brain tissue. Biochem. Pharmacol. 1968, 17, 1285-1297. [CrossRef]

3. Knoll, J.; Magyar, K. Some puzzling pharmacological effects of monoamine oxidase inhibitors. Adv. Biochem. Psychopharmacol. 1972, 5, 393-408. [PubMed]

4. Janes, S.M.; Klinman, J.P. [2] Isolation of 2,4,5-trihydroxyphenylalanine quinone (topa quinone) from copper amine oxidases Methods in Enzymology 1995, 258, 20-34. [CrossRef]

5. Jalkanen, S.; Salmi, M. NEW EMBO MEMBER'S REVIEW: Cell surface monoamine oxidases: Enzymes in search of a function. EMBO J. 2001, 20, 3893-3901. [CrossRef] [PubMed]

6. Klinman, J.P.; Mu, D. Quinoenzymes in Biology. Annu. Rev. Biochem. 1994, 63, 299-344. [CrossRef] [PubMed]

7. Lyles, G. Mammalian plasma and tissue-bound semicarba ide-sensitive amine oxidases: Biochemical, pharmacological and toxicological aspects. Int. J. Biochem. Cell Biol. 1996, 28, 259-274. [CrossRef]

8. O'Sullivan, J.; Unzeta, M.; Healy, J.; O'Sullivan, M.I.; Davey, G.; Tipton, K.F. Semicarbazide-sensitive amine oxidases: En-zymes with quite a lot to do. Neurotoxicology 2004, 25, 303-315. [CrossRef]

9. Lizcano, J.; Balsa, D.; Tipton, K.F.; Unzeta, M. The oxidation of dopamine by the semicarbazide-sensitive amine oxidase (SSAO) from rat vas deferens. Biochem. Pharmacol. 1991, 41, 1107-1110. [CrossRef]

10. De Arriba, A.F.; Lizcano, J.; Balsa, D.; Unzeta, M. Contribution of different amine oxidases to the metabolism of dopamine in bovine retina. Biochem. Pharmacol. 1991, 42, 2355-2361. [CrossRef]

11. Schayer, R.W.; Smiley, R.L.; Kaplan, E. The Metabolism of Epinephrine Containing Isotopic Carbon. II. J. Biol. Chem. 1952, 198, 545-551. [CrossRef]

12. Dar, M.; Morselli, P.; Bowman, E. The enzymatic systems involved in the mammalian metabolism of methylamine. Gen. Pharmacol. Vasc. Syst. 1985, 16, 557-560. [CrossRef]

13. Jones, J.D.; Brunett, P.C. Creatinine metabolism and toxicity. Kidney Int. Suppl. 1975, 294-298.

14. Yu, P.; Deng, Y. Potential cytotoxic effect of chronic administration of creatine, a nutrition supplement to augment athletic performance. Med Hypotheses 2000, 54, 726-728. [CrossRef] [PubMed]

15. Zeisel, S.H.; Wishnok, J.S.; Blusztajn, J.K. Formation of methylamines from ingested choline and lecithin. J. Pharmacol. Exp. Ther. 1983, 225, 320-324. [PubMed]

16. Precious, E.; Gunn, C.E.; Lyles, G.A. Deamination of methylamine by semicarbazidesensitive amine oxidase in human umbilical artery and rat aorta. Biochem. Pharmacol. 1988, 37, 707-713. [CrossRef]

17. Yu, P.H.; Wright, S.; Fan, E.H.; Lun, Z.-R.; Gubisne-Harberle, D. Physiological and pathological implications of semicarbazidesensitive amine oxidase. Biochim. et Biophys. Acta (BBA) -Bioenerg. 2003, 1647, 193-199. [CrossRef]

18. Yu, P.; Zuo, D. Formaldehyde produced endogenously via deamination of methylamine. A potential risk factor for initiation of endothelial injury. Atheroscler. 1996, 120, 189-197. [CrossRef]

19. Bird, M.; Nunn, P.; Lord, L. Formation of glycine and aminoacetone from l-threonine by rat liver mitochondria. Biochim. et Biophys. Acta (BBA) -Gen. Subj. 1984, 802, 229-236. [CrossRef]

20. Kinemuchi, H. Selective Inhibitors of Membrane-Bound Semicarbazide-Sensitive Amine Oxidase (SSAO) Activity in Mammalian Tissues. NeuroToxicology 2004, 25, 325-335. [CrossRef]

21. Esteban, G.; Bolea, I.; Sun, P.; Solé, M.; Samadi, A.; Marco-Contelles, J.; Unzeta, M. A therapeutic approach to cerebrovascular diseases based on indole substituted hydrazides and hydrazines able to interact with human vascular adhesion protein-1, monoamine oxidases (A and B), AChE and BuChE. J. Neural Transm. 2012, 120, 911-918. [CrossRef]

22. Dunkel, P.; Balogh, B.; Meleddu, R.; Maccioni, E.; Gyires, K.; Mátyus, P. Semicarbazide-sensitive amine oxidase/vascular adhesion protein-1: A patent survey. Expert Opin. Ther. Patents 2011, 21, 1453-1471. [CrossRef]

23. Foot, J.S.; Yow, T.T.; Schilter, H.; Buson, A.; Deodhar, M.; Findlay, A.D.; Guo, L.; McDonald, I.A.; Turner, C.I.; Zhou, W.; et al PXS-4681A, a Potent and Selective Mechanism-Based Inhibitor of SSAO/VAP-1 with Anti-Inflammatory Effects In Vivo. J. Pharmacol. Exp. Ther. 2013, 347, 365-374. [CrossRef] [PubMed] 
24. Inoue, T.; Morita, M.; Tojo, T.; Nagashima, A.; Moritomo, A.; Miyake, H. Novel 1H-imidazol-2-amine derivatives as potent and orally active vascular adhesion protein-1 (VAP-1) inhibitors for diabetic macular edema treatment. Bioorganic Med. Chem. 2013, 21, 3873-3881. [CrossRef] [PubMed]

25. Bligt-Lindén, E.; Pihlavisto, M.; Szatmári, I.; Otwinowski, Z.; Smith, D.J.; Lázár, L.; Fülöp, F.; Salminen, T.A. Novel Pyridazinone Inhibitors for Vascular Adhesion Protein-1 (VAP-1): Old Target-New Inhibition Mode. J. Med. Chem. 2013, 56, 9837-9848. [CrossRef] [PubMed]

26. Yamaki, S.; Koga, Y.; Nagashima, A.; Kondo, M.; Shimada, Y.; Kadono, K.; Moritomo, A.; Yoshihara, K. Synthesis and pharmacological evaluation of glycine amide derivatives as novel vascular adhesion protein-1 inhibitors without CYP3A4 and CYP2C19 inhibition. Bioorganic Med. Chem. 2017, 25, 4110-4122. [CrossRef] [PubMed]

27. Salminen, T.A.; Smith, D.J.; Jalkanen, S.; Johnson, M.S. Structural model of the catalytic domain of an enzyme with cell adhe-sion activity: Human vascular adhesion protein-1 (HVAP-1) D4 domain is an amine oxidase. Protein engineering 1998, 11, 1195-1204. [CrossRef] [PubMed]

28. Jakobsson, E.; Nilsson, J.; Ogg, D.; Kleywegt, G.J. Structure of human semicarbazide-sensitive amine oxidase/vascular adhesion protein-1. Acta Crystallogr. Sect. D Biol. Crystallogr. 2005, 61, 1550-1562. [CrossRef] [PubMed]

29. Salmi, M.; Jalkanen, S. A 90-kilodalton endothelial cell molecule mediating lymphocyte binding in humans. Sci. 1992, 257, 1407-1409. [CrossRef] [PubMed]

30. Smith, D.J.; Salmi, M.; Bono, P.; Hellman, J.; Leu, T.; Jalkanen, S. Cloning of Vascular Adhesion Protein 1 Reveals a Novel Multifunctional Adhesion Molecule. J. Exp. Med. 1998, 188, 17-27. [CrossRef]

31. Lewinsohn, R. Mammalian monoamine-oxidizing enzymes, with special reference to benzylamine oxidase in human tissues. Braz. J. Med Biol. Res. 1984, 17, 223-256.

32. Lizcano, J.M.; Balsa, D.; Tipton, K.F.; Unzeta, M. Amine oxidase activities in bovine lung. Amine Oxidases Their Impact Neurobiol. 1990, 32, 341-344. [CrossRef]

33. Lyles, G.A.; Singh, I. Vascular smooth muscle cells: A major source of the semicarbazide-sensitive amine oxidase of the rat aorta. J. Pharm. Pharmacol. 1985, 37, 637-643. [CrossRef] [PubMed]

34. Salmi, M.; Jalkanen, S. Different forms of human vascular adhesion protein-1 (VAP-1) in blood vesselsin vivo and in cultured endothelial cells: Implications for lymphocyte-endothelial cell adhesion models. Eur. J. Immunol. 1995, 25, 2803-2812. [CrossRef] [PubMed]

35. Ramonet, D.; Rodriguez, M.J.; Saura, J.; Lizcano, J.M.; Romera, M.; Unzeta, M.; Finch, C.; Billett, E.; Mahy, N. Localization of monoamine oxidase A and B and semicarbazide-sensitive amine oxidase in human peripheral tissues. Inflammopharmacology 2003, 11, 111-117. [CrossRef]

36. Andrés, N.; Lizcano, J.M.; Rodríguez, M.J.; Romera, M.; Unzeta, M.; Mahy, N. Tissue activity and cellular localization of human semicarbazide-sensitive amine oxidase. J. Histochem. Cytochem. 2001, 49, 209-217. [CrossRef] [PubMed]

37. O'Sullivan, M.; MacDougall, M.B.; Unzeta, M.; Lizcano, J.-M.; Tipton, K.F. Semicarbazide-sensitive amine oxidases in pig dental pulp. Biochim. et Biophys. Acta (BBA)-Bioenerg. 2003, 1647, 333-336. [CrossRef]

38. O'Sullivan, M.; Tipton, K.F.; E McDevitt, W. Immunolocalization of semicarbazide-sensitive amine oxidase in human dental pulp and its activity towards serotonin. Arch. Oral Biol. 2002, 47, 399-406. [CrossRef]

39. Vavilova, T.; Ostrovskaya, I.; Axenova, L.; Buneeva, O.; Medvedev, A. Monoamine oxidase and semicarbazide sensitive amine oxidase activities in normal and inflamed human dental pulp. Med Sci. Monit. 2009, 15, $289-292$.

40. Lizcano, J.M.; Tipton, K.F.; Unzeta, M. Purification and characterization of membrane-bound semicarbazide-sensitive amine oxidase (SSAO) from bovine lung. Biochem. J. 1998, 331, 69-78. [CrossRef] [PubMed]

41. Castillo, V.; Lizcano, J.M.; Visa, J.; Unzeta, M. Semicarbazide-sensitive amine oxidase (SSAO) from human and bovine cerebrovascular tissues: Biochemical and immunohistological characterization. Neurochem. Int. 1998, 33, 415-423. [CrossRef]

42. Morin, N.; Lizcano, J.M.; Fontana, E.; Marti, L.; Smih, F.; Rouet, P.; Prevot, D.; Zorzano, A.; Unzeta, M.; Carpene, C. Semicarbazide-sensitive amine oxidase substrates stimulate glucose transport and inhibit lipolysis in human adipocytes. J Pharma-col Exp. Ther. 2001, 297, 563-572.

43. Salmi, M.; Kalimo, K.; Jalkanen, S. Induction and function of vascular adhesion protein-1 at sites of inflammation. J. Exp. Med. 1993, 178, 2255-2260. [CrossRef]

44. Salmi, M.; Yegutkin, G.G.; Lehvonen, R.; Koskinen, K.; Salminen, T.; Jalkanen, S. A Cell Surface Amine Oxidase Directly Controls Lymphocyte Migration. Immunity 2001, 14, 265-276. [CrossRef]

45. Zuo, D.-M.; Yu, P.H. Semicarbazide-sensitive amine oxidase and monoamine oxidase in rat brain microvessels, meninges, retina and eye sciera. Brain Res. Bull. 1994, 33, 307-311. [CrossRef]

46. Castillo, V.; Lizcano, J.M.; Unzeta, M. Presence of SSAO in human and bovine meninges and microvessels. Neurobiology 1999, 7 , 263-272. [PubMed]

47. Smeraldi, C.; Castillo, V.; Lizcano, J.M.; Unzeta, M. Some properties of semicarbazide-sensitive amine oxidase (SSAO) from human cerebrovascular tissues. Inflamm. Res. 2001, 50, 144-145.

48. Jaakkola, K.; Kaunismäki, K.; Tohka, S.; Yegutkin, G.; Vänttinen, E.; Havia, T.; Pelliniemi, L.J.; Virolainen, M.; Jalkanen, S.; Salmi, M. Human Vascular Adhesion Protein-1 in Smooth Muscle Cells. Am. J. Pathol. 1999, 155, 1953-1965. [CrossRef]

49. Souto, R.P.; Vallega, G.; Wharton, J.; Vinten, J.; Tranum-Jensen, J.; Pilch, P.F. Immunopurification and Characterization of Rat Adipocyte Caveolae Suggest Their Dissociation from Insulin Signaling. J. Biol. Chem. 2003, 278, 18321-18329. [CrossRef] [PubMed] 
50. Brown, D.A.; London, E. Structure and Function of Sphingolipid- and Cholesterol-rich Membrane Rafts. J. Biol. Chem. 2000, 275, 17221-17224. [CrossRef]

51. Boomsma, F.; Bhaggoe, U.M.; Van Der Houwen, A.M.; Meiracker, A.H.V.D. Plasma semicarbazide-sensitive amine oxidase in human (patho)physiology. Biochim. et Biophys. Acta (BBA) -Bioenerg. 2003, 1647, 48-54. [CrossRef]

52. Tipton, K.F.; Strolin Benedetti, M. Amine oxidases and the metabolism of xenobiotics. Enzym. Syst. Metab. Drugs Other Xenobiotics 2001, 95. [CrossRef]

53. Kunsch, C.; Medford, R.M. Oxidative Stress as a Regulator of Gene Expression in the Vasculature. Circ. Res. 1999, 85, 753-766. [CrossRef]

54. Finkel, T. Oxygen radicals and signaling. Curr. Opin. Cell Biol. 1998, 10, 248-253. [CrossRef]

55. Fischer, Y.; Thomas, J.; Sevilla, L.; Muñoz, P.; Becker, C.; Holman, G.; Kozka, I.J.; Palacín, M.; Testar, X.; Kammermeier, H.; et al. Insulin-induced Recruitment of Glucose Transporter 4 (GLUT4) and GLUT1 in Isolated Rat Cardiac Myocytes. J. Biol. Chem. 1997, 272, 7085-7092. [CrossRef]

56. Enrique-Tarancón, G.; Marti, L.; Morin, N.; Lizcano, J.; Unzeta, M.; Sevilla, L.; Camps, M.; Palacín, M.; Testar, X.; Carpéné, C.; et al. Role of Semicarbazide-sensitive Amine Oxidase on Glucose Transport and GLUT4 Recruitment to the Cell Surface in Adipose Cells. J. Biol. Chem. 1998, 273, 8025-8032. [CrossRef] [PubMed]

57. Zorzano, A. Semicarbazide-sensitive amine oxidase activity exerts insulin-like effects on glucose metabolism and insulin-signaling pathways in adipose cells. Biochim. et Biophys. Acta (BBA)-Proteins Proteom. 2003, 1647, 3-9. [CrossRef]

58. Salmi, M.; Jalkanen, S. VAP-1: An adhesin and an enzyme. Trends Immunol. 2001, 22, 211-216. [CrossRef]

59. Butcher, E.C.; Picker, L.J. Lymphocyte Homing and Homeostasis. Science 1996, 272, 60-67. [CrossRef]

60. Salmi, M.; Jalkanen, S. How Do Lymphocytes Know Where to Go: Current Concepts and Enigmas of Lymphocyte Homing. Adv. Immunol. 1997, 64, 139-218. [CrossRef]

61. Springer, T.A. Traffic signals for lymphocyte recirculation and leukocyte emigration: The multistep paradigm. Cell 1994, 76, 301-314. [CrossRef]

62. Salmi, M.; Jalkanen, S. Cell-surface enzymes in control of leukocyte trafficking. Nat. Rev. Immunol. 2005, 5, 760-771. [CrossRef]

63. Lalor, P.F.; Sun, P.J.; Weston, C.J.; Wakelam, M.J.O.; Adams, D.H.; Martin-Santos, A. Activation of vascular adhesion protein-1 on liver endothelium results in an NF-kB-dependent increase in lymphocyte adhesion. Hepatology 2007, 45, 465-474. [CrossRef]

64. Arvilommi, A.-M.; Salmi, M.; Jalkanen, S. Organ-selective regulation of vascular adhesion protein-1 expression in man. Eur. J. Immunol. 1997, 27, 1794-1800. [CrossRef] [PubMed]

65. Tanaka, S.; Tanaka, T.; Kawakami, T.; Takano, H.; Sugahara, M.; Saito, H.; Higashijima, Y.; Yamaguchi, J.; Inagi, R.; Nangaku, M. Vascular adhesion protein-1 enhances neutrophil infiltration by generation of hydrogen peroxide in renal ischemia/reperfusion injury. Kidney Int. 2017, 92, 154-164. [CrossRef] [PubMed]

66. Xu, H.-L.; Salter-Cid, L.; Linnik, M.D.; Wang, E.Y.; Paisansathan, C.; Pelligrino, D.A. Vascular Adhesion Protein-1 Plays an Important Role in Postischemic Inflammation and Neuropathology in Diabetic, Estrogen-Treated Ovariectomized Female Rats Subjected to Transient Forebrain Ischemia. J. Pharmacol. Exp. Ther. 2005, 317, 19-29. [CrossRef]

67. Xu, H.; Testai, F.D.; Valyi-Nagy, T.; Pavuluri, M.N.; Zhai, F.; Nanegrungsunk, D.; Paisansathan, C.; Pelligrino, D.A. VAP-1 blockade prevents subarachnoid hemorrhage-associated cerebrovascular dilating dysfunction via repression of a neutrophil recruitment-related mechanism. Brain Res. 2015, 1603, 141-149. [CrossRef] [PubMed]

68. Ma, Q.; Manaenko, A.; Khatibi, N.H.; Chen, W.; Zhang, J.H.; Tang, J. Vascular Adhesion Protein-1 Inhibition Provides Antiinflammatory Protection after an Intracerebral Hemorrhagic Stroke in Mice. Br. J. Pharmacol. 2010, 31, 881-893. [CrossRef]

69. Merinen, M.; Irjala, H.; Salmi, M.; Jaakkola, I.; Hänninen, A.; Jalkanen, S. Vascular Adhesion Protein-1 Is Involved in Both Acute and Chronic Inflammation in the Mouse. Am. J. Pathol. 2005, 166, 793-800. [CrossRef]

70. Becchi, S.; Buson, A.; Foot, J.; Jarolimek, W.; Balleine, B.W. Inhibition of semicarbazide-sensitive amine oxidase/vascular adhesion protein-1 reduces lipopolysaccharide-induced neuroinflammation. Br. J. Pharmacol. 2017, 174, 2302-2317. [CrossRef]

71. Schilter, H.C.; Collison, A.; Russo, R.C.; Foot, J.S.; Yow, T.T.; Vieira, A.T.; Tavares, L.D.; Mattes, J.; Teixeira, M.M.; Jarolimek, W. Effects of an anti-inflammatory VAP-1/SSAO inhibitor, PXS-4728A, on pulmonary neutrophil migration. Respir. Res. 2015, 16, 1-14. [CrossRef]

72. Tuncer, C.; Oo, Y.H.; Murphy, N.; Adams, D.H.; Lalor, P.F. The regulation of T-cell recruitment to the human liver during acute liver failure. Liver Int. 2013, 33, 852-863. [CrossRef] [PubMed]

73. Bonder, C.S.; Norman, M.U.; Swain, M.G.; Zbytnuik, L.D.; Yamanouchi, J.; Santamaria, P.; Ajuebor, M.; Salmi, M.; Jalkanen, S.; Kubes, P. Rules of Recruitment for Th1 and Th2 Lymphocytes in Inflamed Liver: A Role for Alpha-4 Integrin and Vascular Adhesion Protein-1. Immunity 2005, 23, 153-163. [CrossRef] [PubMed]

74. Aspinall, A.I.; Curbishley, S.M.; Lalor, P.F.; Weston, C.J.; Blahova, M.; Liaskou, E.; Adams, R.M.; Holt, A.P.; Adams, D.H. CX3CR1 and vascular adhesion protein-1-dependent recruitment of CD16+ monocytes across human liver sinusoidal endothelium. Hepatology 2010, 51, 2030-2039. [CrossRef] [PubMed]

75. Shetty, S.; Weston, C.J.; Oo, Y.H.; Westerlund, N.; Stamataki, Z.; Youster, J.; Hubscher, S.G.; Salmi, M.; Jalkanen, S.; Lalor, P.F.; et al. Common Lymphatic Endothelial and Vascular Endothelial Receptor-1 Mediates the Transmigration of Regulatory T Cells across Human Hepatic Sinusoidal Endothelium. J. Immunol. 2011, 186, 4147-4155. [CrossRef] [PubMed] 
76. Martelius, T.; Salmi, M.; Krogerus, L.; Loginov, R.; Schoultz, M.; Karikoski, M.; Miiluniemi, M.; Soots, A.; Höckerstedt, K.; Jalkanen, S.; et al. Inhibition of Semicarbazide-Sensitive Amine Oxidases Decreases Lymphocyte Infiltration in the Early Phases of Rat Liver Allograft Rejection. Int. J. Immunopathol. Pharmacol. 2008, 21, 911-920. [CrossRef] [PubMed]

77. Martelius, T.; Salaspuro, V.; Salmi, M.; Krogerus, L.; Höckerstedt, K.; Jalkanen, S.; Lautenschlager, I. Blockade of Vascular Adhesion Protein-1 Inhibits Lymphocyte Infiltration in Rat Liver Allograft Rejection. Am. J. Pathol. 2004, 165, 1993-2001. [CrossRef]

78. Marttila-Ichihara, F.; Castermans, K.; Auvinen, K.; Egbrink, M.G.A.O.; Jalkanen, S.; Griffioen, A.W.; Salmi, M. Small-Molecule Inhibitors of Vascular Adhesion Protein-1 Reduce the Accumulation of Myeloid Cells into Tumors and Attenuate Tumor Growth in Mice. J. Immunol. 2010, 184, 3164-3173. [CrossRef] [PubMed]

79. Nakao, S.; Noda, K.; Zandi, S.; Sun, D.; Taher, M.; Schering, A.; Xie, F.; Mashima, Y.; Hafezi-Moghadam, A. VAP-1-Mediated M2 Macrophage Infiltration Underlies IL-1 $\beta$ - but Not VEGF-A-Induced Lymph- and Angiogenesis. Am. J. Pathol. 2011, 178, 1913-1921. [CrossRef]

80. Noda, K.; Nakao, S.; Zandi, S.; Engelstädter, V.; Mashima, Y.; Hafezi-Moghadam, A. Vascular adhesion protein-1 regulates leukocyte transmigration rate in the retina during diabetes. Exp. Eye Res. 2009, 89, 774-781. [CrossRef]

81. Noda, K.; Miyahara, S.; Nakazawa, T.; Almulki, L.; Nakao, S.; Hisatomi, T.; She, H.; Thomas, K.L.; Garland, R.C.; Miller, J.W.; et al. Inhibition of vascular adhesion protein-1 suppresses endotoxin-induced uveitis. FASEB J. 2007, 22, 1094-1103. [CrossRef] [PubMed]

82. Salmi, M.; Tohka, S.; Jalkanen, S. Human vascular adhesion protein-1 (VAP-1) plays a critical role in lymphocyte-endothelial cell adhesion cascade under shear. Circ. Res. 2000, 86, 1245-1251. [CrossRef] [PubMed]

83. Koskinen, K.; Vainio, P.J.; Smith, D.J.; Pihlavisto, M.; Ylä-Herttuala, S.; Jalkanen, S.; Salmi, M. Granulocyte transmigration through the endothelium is regulated by the oxidase activity of vascular adhesion protein-1 (VAP-1). Blood 2004, 103, 3388-3395 [CrossRef] [PubMed]

84. Bour, S.; Caspar-Bauguil, S.; Iffiú-Soltész, Z.; Nibbelink, M.; Cousin, B.; Miiluniemi, M.; Salmi, M.; Stolen, C.; Jalkanen, S.; Casteilla, L.; et al. Semicarbazide-Sensitive Amine Oxidase/Vascular Adhesion Protein-1 Deficiency Reduces Leukocyte Infiltration into Adipose Tissue and Favors Fat Deposition. Am. J. Pathol. 2009, 174, 1075-1083. [CrossRef] [PubMed]

85. Matyus, P.; Dajka-Halasz, B.; Foldi, A.; Haider, N.; Barlocco, D.; Magyar, K. Semicarbazide-sensitive amine oxidase: Current status and perspectives. Curr. Med. Chem. 2004, 11, 1285-1298. [CrossRef] [PubMed]

86. Solé, M.; Hernandez-Guillamon, M.; Boada, M.; Unzeta, M. p53 phosphorylation is involved in vascular cell death induced by the catalytic activity of membrane-bound SSAO/VAP-1. Biochim. et Biophys. Acta (BBA) -Bioenerg. 2008, 1783, 1085-1094. [CrossRef] [PubMed]

87. Dhar, A.; Desai, K.; Kazachmov, M.; Yu, P.; Wu, L. Methylglyoxal production in vascular smooth muscle cells from different metabolic precursors. Metabolism 2008, 57, 1211-1220. [CrossRef]

88. Mathys, K.C.; Ponnampalam, S.N.; Padival, S.; Nagaraj, R.H. Semicarbazide-sensitive amine oxidase in aortic smooth muscle cells mediates synthesis of a methylglyoxal-AGE: Implications for vascular complications in diabetes. Biochem. Biophys. Res. Commun. 2002, 297, 863-869. [CrossRef]

89. Kurkijärvi, R.; Adams, D.H.; Leino, R.; Möttönen, T.; Jalkanen, S.; Salmi, M. Circulating form of human vascular adhesion protein-1 (VAP-1): Increased serum levels in inflammatory liver diseases. J. Immunol. 1998, 161, $1549-1557$.

90. Kurkijärvi, R.; Yegutkin, G.G.; Gunson, B.K.; Jalkanen, S.; Salmi, M.; Adams, D.H. Circulating soluble vascular adhesion protein 1 accounts for the increased serum monoamine oxidase activity in chronic liver disease. Gastroenterology 2000, 119, 1096-1103. [CrossRef]

91. Boomsma, F.; van Veldhuisen, D.J.; de Kam, P.J.; Man in't Veld, A.J.; Mosterd, A.; Lie, K.I.; Schalekamp, M.A. Plasma semicarbazide-sensitive amine oxidase is elevated in patients with congestive heart failure. Cardiovasc. Res. 1997, 33, 387-391. [CrossRef]

92. Hernandez-Guillamon, M.; Garcia-Bonilla, L.; Solé, M.; Sosti, V.; Parés, M.; Campos, M.; Ortega-Aznar, A.; Domínguez, C.; Rubiera, M.; Ribó, M.; et al. Plasma VAP-1/SSAO Activity Predicts Intracranial Hemorrhages and Adverse Neurological Outcome After Tissue Plasminogen Activator Treatment in Stroke. Stroke 2010, 41, 1528-1535. [CrossRef] [PubMed]

93. Garpenstrand, H.; Ekblom, J.; Von Arbin, M.; Oreland, L.; Murray, V. Plasma Semicarbazide-Sensitive Amine Oxidase in Stroke. Eur. Neurol. 1999, 41, 20-23. [CrossRef] [PubMed]

94. Ishizaki, F. Plasma Benzylamine Oxidase Activity in Cerebrovascular Disease. Eur. Neurol. 1990, 30, 104-107. [CrossRef] [PubMed]

95. Hernández-Guillamon, M.; Solé, M.; Delgado, P.; García-Bonilla, L.; Giralt, D.; Boada, C.; Penalba, A.; Garcia, S.; Flores, A.; Ribó, M.; et al. VAP-1/SSAO Plasma Activity and Brain Expression in Human Hemorrhagic Stroke. Cerebrovasc. Dis. 2012, $33,55-63$. [CrossRef]

96. Ferrer, I.; Lizcano, J.; Hernández, M.; Unzeta, M. Overexpression of semicarbazide sensitive amine oxidase in the cerebral blood vessels in patients with Alzheimer's disease and cerebral autosomal dominant arteriopathy with subcortical infarcts and leukoencephalopathy. Neurosci. Lett. 2002, 321, 21-24. [CrossRef]

97. Hernandez, M.D.M.; Esteban, M.; Szabo, P.; Boada, M.; Unzeta, M. Human plasma semicarbazide sensitive amine oxidase (SSAO), $\beta$-amyloid protein and aging. Neurosci. Lett. 2005, 384, 183-187. [CrossRef] [PubMed]

98. Tong, Z.; Wang, W.; Luo, W.; Lv, J.; Li, H.; Luo, H.; Jia, J.; He, R. Urine Formaldehyde Predicts Cognitive Impairment in Post-Stroke Dementia and Alzheimer's Disease. J. Alzheimer's Dis. 2016, 55, 1031-1038. [CrossRef] [PubMed] 
99. Brands, A.M.; Kessels, R.P.; De Haan, E.H.; Kappelle, L.; Biessels, G.J. Cerebral dysfunction in type 1 diabetes: Effects of insulin, vascular risk factors and blood-glucose levels. Eur. J. Pharmacol. 2004, 490, 159-168. [CrossRef]

100. Carro, E.; Torres-Aleman, I. The role of insulin and insulin-like growth factor I in the molecular and cellular mechanisms underlying the pathology of Alzheimer's disease. Eur. J. Pharmacol. 2004, 490, 127-133. [CrossRef] [PubMed]

101. Doble, B.W.; Woodgett, J.R. GSK-3: Tricks of the trade for a multi-tasking kinase. J. Cell Sci. 2003, 116, 1175-1186. [CrossRef] [PubMed]

102. Haan, M.N. Therapy Insight: Type 2 diabetes mellitus and the risk of late-onset Alzheimer's disease. Nat. Clin. Pract. Neurol. 2006, 2, 159-166. [CrossRef] [PubMed]

103. Garpenstrand, H.; Ekblom, J.; Backlund, L.B.; Oreland, L.; Rosenqvist, U. Elevated plasma semicarbazide-sensitive amine oxidase (SSAO) activity in Type 2 diabetes mellitus complicated by retinopathy. Diabet. Med. 1999, 16, 514-521. [CrossRef]

104. Irjala, H.; Salmi, M.; Alanen, K.; Grénman, R.; Jalkanen, S. Vascular Adhesion Protein 1 Mediates Binding of Immunotherapeutic Effector Cells to Tumor Endothelium. J. Immunol. 2001, 166, 6937-6943. [CrossRef] [PubMed]

105. Abella, A.; Garcia-Vicente, S.; Viguerie, N.; Ros-Baro, A.; Camps, M.; Palacín, M.; Zorzano, A.; Marti, L. Adipocytes release a soluble form of VAP-1/SSAO by a metalloprotease-dependent process and in a regulated manner. Diabetologia 2004, 47, 429-438. [CrossRef]

106. Stolen, C.M.; Yegutkin, G.G.; Kurkijärvi, R.; Bono, P.; Alitalo, K.; Jalkanen, S. Origins of Serum Semicarbazide-Sensitive Amine Oxidase. Circ. Res. 2004, 95, 50-57. [CrossRef] [PubMed]

107. Boomsma, F.; Meiracker, A.H.V.D.; Winkel, S.; Aanstoot, H.J.; Batstra, M.R.; Veld, A.J.M.I. 'T; Bruining, G.J. Circulating semicarbazide-sensitive amine oxidase is raised both in Type I (insulin-dependent), in Type II (non-insulin-dependent) diabetes mellitus and even in childhood Type I diabetes at first clinical diagnosis. Diabetologia 1999, 42, 233-237. [CrossRef] [PubMed]

108. Mészáros, Z.; Karádi, I.; Csányi, A.; Szombathy, T.; Romics, L.; Magyar, K. Determination of human serum semicarbazidesensitive amine oxidase activity: A possible clinical marker of atherosclerosis. Eur. J. Drug Metab. Pharmacokinet. 1999, 24, 299-302. [CrossRef]

109. Grönvall-Nordquist, J.L.; Bäcklund, L.B.; Garpenstrand, H.; Ekblom, J.; Landin, B.; Yu, P.H.; Oreland, L.; Rosenqvist, U. Follow-up of plasma semicarbazide-sensitive amine oxidase activity and retinopathy in Type 2 diabetes mellitus. J. Diabetes its Complicat. 2001, 15, 250-256. [CrossRef]

110. Karádi, I.; Mészáros, Z.; Csányi, A.; Szombathy, T.; Hosszúfalusi, N.; Romics, L.; Magyar, K. Serum semicarbazide-sensitive amine oxidase (SSAO) activity is an independent marker of carotid atherosclerosis. Clin. Chim. Acta 2002, 323, 139-146. [CrossRef]

111. Weiss, H.G.; Klocker, J.; Labeck, B.; Nehoda, H.; Aigner, F.; Klingler, A.; Ebenbichler, C.; Föger, B.; Lechleitner, M.; Patsch, J.R.; et al. Plasma amine oxidase: A postulated cardiovascular risk factor in nondiabetic obese patients. Metabolism 2003, 52, 688-692. [CrossRef]

112. Yu, P.H.; Zuo, D.-M. Oxidative Deamination of Methylamine by Semicarbazide-Sensitive Amine Oxidase Leads to Cytotoxic Damage in Endothelial Cells: Possible Consequences for Diabetes. Diabetes 1993, 42, 594-603. [CrossRef] [PubMed]

113. Smith, D.J.; Vainio, P.J. Targeting Vascular Adhesion Protein-1 to Treat Autoimmune and Inflammatory Diseases. Ann. New York Acad. Sci. 2007, 1110, 382-388. [CrossRef] [PubMed]

114. Lewinsohn, R. Human serum amine oxidase. Enzyme activity in severely burnt patients and in patients with cancer. Clin. Chim. Acta 1977, 81, 247-256. [CrossRef]

115. Lizcano, J.; Escrich, E.; Ribalta, T.; Muntané, J.; Unzeta, M. Amine oxidase activities in rat breast cancer induced experimentally with 7,12-dimethylbenz( $\alpha$ anthracene. Biochem. Pharmacol. 1991, 42, 263-269. [CrossRef]

116. Chang, S.-J.; Tu, H.-P.; Lai, Y.-C.C.; Luo, C.-W.; Nejo, T.; Tanaka, S.; Chai, C.-Y.; Kwan, A.-L. Increased Vascular Adhesion Protein 1 (VAP-1) Levels Are Associated with Alternative M2 Macrophage Activation and Poor Prognosis for Human Gliomas. Diagnostics 2020, 10, 256. [CrossRef] [PubMed]

117. Kostoro, J.; Chang, S.-J.; Lai, Y.-C.C.; Wu, C.-C.; Chai, C.-Y.; Kwan, A.-L. Overexpression of vascular adhesion protein-1 is associated with poor prognosis of astrocytomas. APMIS 2016, 124, 462-468. [CrossRef]

118. Airas, L.; Mikkola, J.; Vainio, J.M.; Elovaara, I.; Smith, D.J. Elevated serum soluble vascular adhesion protein-1 (VAP-1) in patients with active relapsing remitting multiple sclerosis. J. Neuroimmunol. 2006, 177, 132-135. [CrossRef]

119. Elo, P.; Tadayon, S.; Liljenbäck, H.; Teuho, J.; Käkelä, M.; Koskensalo, K.; Saunavaara, V.; Virta, J.; Veres, T.Z.; Kiviniemi, A. Vascular adhesion protein-1 is actively involved in the development of inflammatory lesions in rat models of multiple sclero-sis. J. Neuroinflammation 2018, 15, 1-17. [CrossRef]

120. Pannecoeck, R.; Serruys, D.; Benmeridja, L.; Delanghe, J.R.; Van Geel, N.; Speeckaert, R.; Speeckaert, M.M. Vascular adhesion protein-1: Role in human pathology and application as a biomarker. Crit. Rev. Clin. Lab. Sci. 2015, 52, 284-300. [CrossRef]

121. Ballabh, P.; Braun, A.; Nedergaard, M. The blood-brain barrier: An overview. Neurobiol. Dis. 2004, 16, 1-13. [CrossRef] [PubMed]

122. Abbott, N.J.; Patabendige, A.A.; Dolman, D.E.; Yusof, S.R.; Begley, D.J. Structure and function of the blood-brain barrier. Neurobiol. Dis. 2010, 37, 13-25. [CrossRef] [PubMed]

123. Zlokovic, B.V. The Blood-Brain Barrier in Health and Chronic Neurodegenerative Disorders. Neuron 2008, 57, 178-201. [CrossRef]

124. Zlokovic, B.V. Neurovascular pathways to neurodegeneration in Alzheimer's disease and other disorders. Nat. Rev. Neurosci. 2011, 12, 723-738. [CrossRef] [PubMed] 
125. Zenaro, E.; Piacentino, G.; Constantin, G. The blood-brain barrier in Alzheimer's disease. Neurobiol. Dis. 2017, 107, 41-56. [CrossRef] [PubMed]

126. Kalaria, R.N. Cerebral vessels in ageing and Alzheimer's disease. Pharmacol. Ther. 1996, 72, 193-214. [CrossRef]

127. Kisler, K.; Nelson, A.R.; Montagne, A.; Zlokovic, B.V. Cerebral blood flow regulation and neurovascular dysfunction in Alzheimer disease. Nat. Rev. Neurosci. 2017, 18, 419-434. [CrossRef] [PubMed]

128. Montagne, A.; Barnes, S.R.; Sweeney, M.D.; Halliday, M.R.; Sagare, A.P.; Zhao, Z.; Toga, A.W.; Jacobs, R.E.; Liu, C.Y.; Amezcua, L.; et al. Blood-Brain Barrier Breakdown in the Aging Human Hippocampus. Neuron 2015, 85, 296-302. [CrossRef] [PubMed]

129. Cai, W.; Zhang, K.; Li, P.; Zhu, L.; Xu, J.; Yang, B.; Hu, X.; Lu, Z.; Chen, J. Dysfunction of the neurovascular unit in ischemic stroke and neurodegenerative diseases: An aging effect. Ageing Res. Rev. 2017, 34, 77-87. [CrossRef] [PubMed]

130. Takechi, R.; Lam, V.; Brook, E.; Giles, C.; Fimognari, N.; Mooranian, A.; Al-Salami, H.; Coulson, S.H.; Nesbit, M.; Mamo, J.C.L. Blood-Brain Barrier Dysfunction Precedes Cognitive Decline and Neurodegeneration in Diabetic Insulin Resistant Mouse Model: An Implication for Causal Link. Front. Aging Neurosci. 2017, 9, 399. [CrossRef]

131. Toth, P.; Tarantini, S.; Csiszar, A.; Ungvari, Z. Functional vascular contributions to cognitive impairment and dementia: Mechanisms and consequences of cerebral autoregulatory dysfunction, endothelial impairment, and neurovascular uncoupling in aging. Am. J. Physiol. Circ. Physiol. 2017, 312, H1-H20. [CrossRef] [PubMed]

132. Zlokovic, B.V. Neurovascular mechanisms of Alzheimer's neurodegeneration. Trends Neurosci. 2005, 28, 202-208. [CrossRef] [PubMed]

133. Zacchigna, S.; Lambrechts, D.; Carmeliet, P. Neurovascular signalling defects in neurodegeneration. Nat. Rev. Neurosci. 2008, 9 , 169-181. [CrossRef] [PubMed]

134. Greenberg, D.A.; Jin, K. From angiogenesis to neuropathology. Nat. Cell Biol. 2005, 438, 954-959. [CrossRef] [PubMed]

135. Iadecola, C. Neurovascular regulation in the normal brain and in Alzheimer's disease. Nat. Rev. Neurosci. 2004, 5, 347-360. [CrossRef] [PubMed]

136. Morrison, H.W.; Filosa, J.A. Stroke and the neurovascular unit: Glial cells, sex differences, and hypertension. Am. J. Physiol. Physiol. 2019, 316, C325-C339. [CrossRef] [PubMed]

137. Michalicova, A.; A Banks, W.; Legath, J.; Kovac, A. Tauopathies-focus on changes at the neurovascular unit. Curr. Alz-heimer Res. 2017, 14, 790-801. [CrossRef] [PubMed]

138. Hill, J.; Rom, S.; Ramirez, S.H.; Persidsky, Y. Emerging Roles of Pericytes in the Regulation of the Neurovascular Unit in Health and Disease. J. Neuroimmune Pharmacol. 2014, 9, 591-605. [CrossRef]

139. Grammas, P. Neurovascular dysfunction, inflammation and endothelial activation: Implications for the pathogenesis of Alzheimer's disease. J. Neuroinflammation 2011, 8, 26. [CrossRef] [PubMed]

140. Sweeney, M.D.; Zhao, Z.; Montagne, A.; Nelson, A.R.; Zlokovic, B.V. Blood-Brain Barrier: From Physiology to Disease and Back. Physiol. Rev. 2019, 99, 21-78. [CrossRef]

141. Woodruff, T.M.; Thundyil, J.; Tang, S.-C.; Sobey, C.G.; Taylor, S.M.; Arumugam, T.V. Pathophysiology, treatment, and animal and cellular models of human ischemic stroke. Mol. Neurodegener. 2011, 6, 11-19. [CrossRef] [PubMed]

142. Doyle, K.P.; Simon, R.P.; Stenzel-Poore, M.P. Mechanisms of ischemic brain damage. Neuropharmacology 2008, 55, 310-318. [CrossRef]

143. Lo, E.H.; Dalkara, T.; Moskowitz, M.A. Mechanisms, challenges and opportunities in stroke. Nat. Rev. Neurosci. 2003, 4, 399-414. [CrossRef]

144. E Lakhan, S.; Kirchgessner, A.; Hofer, M. Inflammatory mechanisms in ischemic stroke: Therapeutic approaches. J. Transl. Med. 2009, 7, 97. [CrossRef]

145. Fiskum, G.; Murphy, A.N.; Beal, M.F. Mitochondria in Neurodegeneration: Acute Ischemia and Chronic Neurodegenerative Diseases. Br. J. Pharmacol. 1999, 19, 351-369. [CrossRef] [PubMed]

146. Chan, P.H. Reactive Oxygen Radicals in Signaling and Damage in the Ischemic Brain. Br. J. Pharmacol. 2001, 21, 2-14. [CrossRef] [PubMed]

147. Arumugam, T.V.; Woodruff, T.M.; Lathia, J.D.; Selvaraj, P.K.; Mattson, M.P.; Taylor, S.M. Neuroprotection in stroke by complement inhibition and immunoglobulin therapy. Neuroscience 2009, 158, 1074-1089. [CrossRef] [PubMed]

148. Lucas, S.-M.; Rothwell, N.J.; Gibson, R.M. The role of inflammation in CNS injury and disease. Br. J. Pharmacol. 2006, 147, S232-S240. [CrossRef]

149. Swanson, R.A.; Ying, W.; Kauppinen, T.M. Astrocyte Influences on Ischemic Neuronal Death. Curr. Mol. Med. 2004, 4, 193-205. [CrossRef]

150. Schroeter, M.; Jander, S.; Witte, O.W.; Stoll, G. Local immune responses in the rat cerebral cortex after middle cerebral artery occlusion. J. Neuroimmunol. 1994, 55, 195-203. [CrossRef]

151. Zhang, R.; Chopp, M.; Zhang, Z.; Jiang, N.; Powers, C. The expression of P- and E-selectins in three models of middle cerebral artery occlusion. Brain Res. 1998, 785, 207-214. [CrossRef]

152. Lindsberg, P.J.; Carpe' n, O.; Paetau, A.; Karjalainen-Lindsberg, M.-L.; Kaste, M. Endothelial ICAM-1 expression associated with inflammatory cell response in human ischemic stroke. Circulation 1996, 94, 939-945. [CrossRef]

153. Rallidis, L.S.; Zolindaki, M.G.; Vikelis, M.; Kaliva, K.; Papadopoulos, C.; Kremastinos, D.T. Elevated soluble intercellular ad-hesion molecule-1 levels are associated with poor short-term prognosis in middle-aged patients with acute ischaemic stroke. Int. J. Cardiol. 2009, 132, 216-220. [CrossRef] 
154. Kivipelto, M.; Helkala, E.-L.; Laakso, M.P.; Hänninen, T.; Hallikainen, M.; Alhainen, K.; Soininen, H.; Tuomilehto, J.; Nissinen, A. Midlife vascular risk factors and Alzheimer's disease in later life: Longitudinal, population based study. BMJ 2001, 322, 1447-1451. [CrossRef]

155. Mayeux, R. Epidemiology Ofneurodegeneration. Annu. Rev. Neurosci. 2003, 26, 81-104. [CrossRef] [PubMed]

156. Levy-Lahad, E.; Wasco, W.; Poorkaj, P.; Romano, D.M.; Oshima, J.; Pettingell, W.H.; Yu, C.E.; Jondro, P.D.; Schmidt, S.D.; Wang, K.; et al. Candidate gene for the chromosome 1 familial Alzheimer's disease locus. Science 1995, 269, 973-977. [CrossRef] [PubMed]

157. Sherrington, R.; Rogaev, E.I.; Liang, Y.; Rogaeva, E.A.; Levesque, G.; Ikeda, M.; Chi, H.; Lin, C.; Li, G.; Holman, K.; et al. Cloning of a gene bearing missense mutations in early-onset familial Alzheimer's disease. Nature 1995, 375, 754-760. [CrossRef] [PubMed]

158. Corder, E.H.; Saunders, A.M.; Strittmatter, W.J.; Schmechel, D.E.; Gaskell, P.C.; Small, G.W.; Roses, A.D.; Haines, J.L.; PericakVance, M.A. Gene dose of apolipoprotein E type 4 allele and the risk of Alzheimer's disease in late onset families. Science 1993, 261, 921-923. [CrossRef] [PubMed]

159. Poirier, J.; Bertrand, P.; Kogan, S.; Gauthier, S.; Davignon, J.; Bouthillier, D. Apolipoprotein E polymorphism and Alzheimer's disease. Lancet 1993, 342, 697-699. [CrossRef]

160. Solis, E., Jr.; Hascup, K.N.; Hascup, E.R. Alzheimer's disease: The link between amyloid- $\beta$ and neurovascular dysfunction. J. Alzheimer's Dis. 2020, 76, 1179-1198. [CrossRef] [PubMed]

161. Hardy, J.A.; Higgins, G.A. Alzheimer's disease: The amyloid cascade hypothesis. Science 1992, 256, 184-185. [CrossRef] [PubMed]

162. Selkoe, D.J. Alzheimer's Disease: Genes, Proteins, and Therapy. Physiol. Rev. 2001, 81, 741-766. [CrossRef]

163. Vassar, R. BACE1: The $\beta$-Secretase Enzyme in Alzheimer's Disease. J. Mol. Neurosci. 2004, 23, 105-114. [CrossRef]

164. Hussain, I.; Powell, D.; Howlett, D.R.; Tew, D.G.; Meek, T.D.; Chapman, C.; Gloger, I.S.; Murphy, K.E.; Southan, C.D.; Ryan, D.M.; et al. Identification of a Novel Aspartic Protease (Asp 2) as $\beta$-Secretase. Mol. Cell. Neurosci. 1999, 14, 419-427. [CrossRef] [PubMed]

165. Sinha, S.; Anderson, J.P.; Barbour, R.; Basi, G.S.; Caccavello, R.; Davis, D.; Doan, M.; Dovey, H.F.; Frigon, N.; Hong, J. Puri-fication and cloning of amyloid precursor protein $\beta$-secretase from human brain. Nature 1999, 402, 537-540. [CrossRef]

166. Hardy, J.; Selkoe, D.J. The amyloid hypothesis of Alzheimer's disease: Progress and problems on the road to therapeutics. Science 2002, 297, 353-356. [CrossRef] [PubMed]

167. Carson, J.A.; Turner, A.J. $\beta$-Amyloid catabolism: Roles for neprilysin (NEP) and other metallopeptidases? J. Neurochem. 2002, 81, 1-8. [CrossRef]

168. Tarasoff-Conway, J.M.; Carare, R.O.; Osorio, R.S.; Glodzik, L.; Butler, T.; Fieremans, E.; Axel, L.; Rusinek, H.; Nicholson, C.; Zlokovic, B.V.; et al. Clearance systems in the brain-implications for Alzheimer disease. Nat. Rev. Neurol. 2015, 11, 457-470. [CrossRef]

169. Tanzi, R.; Moir, R.; Wagner, S. Clearance of Alzheimer's A $\beta$ Peptide. Neuron 2004, 43, 605-608. [CrossRef] [PubMed]

170. Deane, R.; Wu, Z.; Sagare, A.; Davis, J.; Du Yan, S.; Hamm, K.; Xu, F.; Parisi, M.; LaRue, B.; Hu, H.W.; et al. LRP/Amyloid $\beta$-Peptide Interaction Mediates Differential Brain Efflux of A $\beta$ Isoforms. Neuron 2004, 43, 333-344. [CrossRef]

171. Deane, R.; Du Yan, S.; Submamaryan, R.K.; LaRue, B.; Jovanovic, S.; Hogg, E.; Welch, D.; Manness, L.; Lin, C.; Yu, J.; et al. RAGE mediates amyloid- $\beta$ peptide transport across the blood-brain barrier and accumulation in brain. Nat. Med. 2003, 9, 907-913. [CrossRef]

172. Van Nostrand, W.E.; Melchor, J.P.; Romanov, G.; Zeigler, K.; Davis, J. Pathogenic Effects of Cerebral Amyloid Angiopathy Mutations in the Amyloid $\beta$-Protein Precursor. Ann. N. Y. Acad. Sci. 2002, 977, 258-265. [CrossRef] [PubMed]

173. Revesz, T.; Holton, J.L.; Lashley, T.; Plant, G.; Rostagno, A.; Ghiso, J.; Frangione, B. Sporadic and familial cerebral amyloid angiopathies. Brain Pathol. 2006, 12, 343-357. [CrossRef]

174. Greenberg, S.M.; Bacskai, B.J.; Hernandez-Guillamon, M.; Pruzin, J.; Sperling, R.; Van Veluw, S.J. Cerebral amyloid angiopathy and Alzheimer disease - one peptide, two pathways. Nat. Rev. Neurol. 2020, 16, 30-42. [CrossRef] [PubMed]

175. Charidimou, A.; Boulouis, G.; Gurol, M.E.; Ayata, C.; Bacskai, B.J.; Frosch, M.P.; Viswanathan, A.; Greenberg, S.M. Emerging concepts in sporadic cerebral amyloid angiopathy. Brain 2017, 140, 1829-1850. [CrossRef] [PubMed]

176. Arvanitakis, Z.; Leurgans, S.E.; Wang, Z.; Wilson, R.S.; Bennett, D.A.; Schneider, J.A. Cerebral amyloid angiopathy pathology and cognitive domains in older persons. Ann. Neurol. 2010, 69, 320-327. [CrossRef]

177. Wattendorff, A.R.; Frangione, B.; Luyendijk, W.; Bots, G.T. Hereditary cerebral haemorrhage with amyloidosis, Dutch type (HCHWA-D): Clinicopathological studies. J. Neurol. Neurosurg. Psychiatry 1995, 58, 699-705. [CrossRef] [PubMed]

178. Grammas, P. A damaged microcirculation contributes to neuronal cell death in Alzheimer's disease次. Neurobiol. Aging 2000, 21, 199-205. [CrossRef]

179. Snyder, H.M.; Corriveau, R.A.; Craft, S.; Faber, J.E.; Greenberg, S.M.; Knopman, D.; Lamb, B.T.; Montine, T.J.; Nedergaard, M.; Schaffer, C.B.; et al. Vascular contributions to cognitive impairment and dementia including Alzheimer's disease. Alzheimer's Dement. 2015, 11, 710-717. [CrossRef]

180. Iturria-Medina, Y.; Initiative, T.A.D.N.; Sotero, R.C.; Toussaint, P.J.; Mateos-Pérez, J.M.; Evans, A.C. Early role of vascular dysregulation on late-onset Alzheimer's disease based on multifactorial data-driven analysis. Nat. Commun. 2016, 7, 11934. [CrossRef] [PubMed]

181. Wierenga, C.E.; Hays, C.C.; Zlatar, Z.Z. Cerebral Blood Flow Measured by Arterial Spin Labeling MRI as a Preclinical Marker of Alzheimer's Disease. J. Alzheimer's Dis. 2014, 42, S411-S419. [CrossRef] [PubMed] 
182. Wang, X.; Xing, A.; Xu, C.; Cai, Q.; Liu, H.; Li, L. Cerebrovascular Hypoperfusion Induces Spatial Memory Impairment, Synaptic Changes, and Amyloid- $\beta$ Oligomerization in Rats. J. Alzheimer's Dis. 2010, 21, 813-822. [CrossRef] [PubMed]

183. Van De Haar, H.J.; Burgmans, S.; Jansen, J.F.A.; Van Osch, M.J.P.; Van Buchem, M.A.; Muller, M.; Hofman, P.A.M.; Verhey, F.R.J.; Backes, W.H. Blood-Brain Barrier Leakage in Patients with Early Alzheimer Disease. Radiology 2017, 282, 615. [CrossRef] [PubMed]

184. Aliev, G.; Priyadarshini, M.; P Reddy, V.; Grieg, N.H.; Kaminsky, Y.; Cacabelos, R.; Md Ashraf, G.; Jabir, N.R.; Kamal, M.A.; Nikolenko, V. Oxidative stress mediated mitochondrial and vascular lesions as markers in the pathogenesis of Alzheimer disease. Curr. Med. Chem. 2014, 21, 2208-2217. [CrossRef] [PubMed]

185. Grammas, P. Inflammatory factors are elevated in brain microvessels in Alzheimer's disease. Neurobiol. Aging 2001, 22, 837-842. [CrossRef]

186. Suo, Z.; Tan, J.; Placzek, A.; Crawford, F.; Fang, C.; Mullan, M. Alzheimer's $\beta$-amyloid peptides induce inflammatory cascade in human vascular cells: The roles of cytokines and CD40. Brain Res. 1998, 807, 110-117. [CrossRef]

187. Thirumangalakudi, L.; Samany, P.G.; Owoso, A.; Wiskar, B.; Grammas, P. Angiogenic proteins are expressed by brain blood vessels in Alzheimer's disease. J. Alzheimer's Dis. 2006, 10, 111-118. [CrossRef] [PubMed]

188. Zuliani, G.; Cavalieri, M.; Galvani, M.; Passaro, A.; Munari, M.; Bosi, C.; Zurlo, A.; Fellin, R. Markers of endothelial dysfunction in older subjects with late onset Alzheimer's disease or vascular dementia. J. Neurol. Sci. 2008, 272, 164-170. [CrossRef]

189. MacKenzie, I.R.; Hao, C.; Muñoz, D.G. Role of microglia in senile plaque formation. Neurobiol. Aging 1995, 16, 797-804. [CrossRef]

190. Emmerling, M.R.; Watson, M.; Raby, C.A.; Spiegel, K. The role of complement in Alzheimer's disease pathology. Biochim. et Biophys. Acta (BBA)-Mol. Basis Dis. 2000, 1502, 158-171. [CrossRef]

191. Michaud, J.-P.; Hallé, M.; Lampron, A.; Thériault, P.; Préfontaine, P.; Filali, M.; Tribout-Jover, P.; Lanteigne, A.-M.; Jodoin, R.; Cluff, C.; et al. Toll-like receptor 4 stimulation with the detoxified ligand monophosphoryl lipid A improves Alzheimer's disease-related pathology. Proc. Natl. Acad. Sci. USA 2013, 110, 1941-1946. [CrossRef]

192. Lue, L.-F.; Brachova, L.; Civin, W.H.; Rogers, J. Inflammation, A $\beta$ deposition, and neurofibrillary tangle formation as corre-lates of Alzheimer's disease neurodegeneration. J. Neuropathol. Exp. Neurol. 1996, 55, 1083-1088. [CrossRef] [PubMed]

193. Airas, L.; Lindsberg, P.J.; Karjalainen-Lindsberg, M.-L.; Mononen, I.; Kotisaari, K.; Smith, D.J.; Jalkanen, S. Vascular adhesion protein-1 in human ischaemic stroke. Neuropathol. Appl. Neurobiol. 2008, 34, 394-402. [CrossRef] [PubMed]

194. Ziliotto, N.; Zivadinov, R.; Jakimovski, D.; Bergsland, N.; Ramasamy, D.P.; Weinstock-Guttman, B.; Ramanathan, M.; Marchetti, G.; Bernardi, F. Are Plasma Levels of Vascular Adhesion Protein-1 Associated Both with Cerebral Microbleeds in Multiple Sclerosis and Intracerebral Haemorrhages in Stroke? Thromb. Haemost. 2018, 119, 175-178. [CrossRef]

195. Kiss, J.; Jalkanen, S.; Fülöp, F.; Savunen, T.; Salmi, M. Ischemia-reperfusion injury is attenuated in VAP-1-deficient mice and by VAP-1 inhibitors. Eur. J. Immunol. 2008, 38, 3041-3049. [CrossRef]

196. Yang, W.; Li, H.; Luo, H.; Luo, W. Inhibition of semicarbazide-sensitive amine oxidase attenuates myocardial ischemia-reperfusion injury in an in vivo rat model. Life Sci. 2011, 88, 302-306. [CrossRef] [PubMed]

197. Jalkanen, S.; Karikoski, M.; Mercier, N.; Koskinen, K.; Henttinen, T.; Elima, K.; Salmivirta, K.; Salmi, M. The oxidase activity of vascular adhesion protein-1 (VAP-1) induces endothelial E- and P-selectins and leukocyte binding. Blood 2007, 110, 1864-1870. [CrossRef] [PubMed]

198. Sun, P.; Hernandez-Guillamón, M.; Campos-Martorell, M.; Simats, A.; Montaner, J.; Unzeta, M.; Solé, M. Simvastatin blocks soluble SSAO/VAP-1 release in experimental models of cerebral ischemia: Possible benefits for stroke-induced inflammation control. Biochim. et Biophys. Acta (BBA) -Mol. Basis Dis. 2018, 1864, 542-553. [CrossRef]

199. Sun, P.; Solé, M.; Unzeta, M. Involvement of SSAO/VAP-1 in Oxygen-Glucose Deprivation-Mediated Damage Using the Endothelial hSSAO/VAP-1-Expressing Cells as an Experimental Model of Cerebral Ischemia. Cerebrovasc. Dis. 2014, 37, 171-180. [CrossRef] [PubMed]

200. Hernandez, M.; Solé, M.; Boada, M.; Unzeta, M. Soluble Semicarbazide Sensitive Amine Oxidase (SSAO) catalysis induces apoptosis in vascular smooth muscle cells. Biochim. et Biophys. Acta (BBA) -Bioenerg. 2006, 1763, 164-173. [CrossRef] [PubMed]

201. Yu, P. Involvement of cerebrovascular semicarbazide-sensitive amine oxidase in the pathogenesis of Alzheimer's disease and vascular dementia. Med. Hypotheses 2001, 57, 175-179. [CrossRef]

202. Valente, T.; Gella, A.; Fernàndez-Busquets, X.; Unzeta, M.; Durany, N. Immunohistochemical analysis of human brain suggests pathological synergism of Alzheimer's disease and diabetes mellitus. Neurobiol. Dis. 2010, 37, 67-76. [CrossRef] [PubMed]

203. Gudala, K.; Bansal, D.; Schifano, F.; Bhansali, A. Diabetes mellitus and risk of dementia: A meta-analysis of prospective observational studies. J. Diabetes Investig. 2013, 4, 640-650. [CrossRef] [PubMed]

204. Valente, T.; Gella, A.; Solé, M.; Durany, N.; Unzeta, M. Immunohistochemical study of semicarbazide-sensitive amine oxidase/vascular adhesion protein-1 in the hippocampal vasculature: Pathological synergy of Alzheimer's disease and diabetes mellitus. J. Neurosci. Res. 2012, 90, 1989-1996. [CrossRef] [PubMed]

205. Broce, I.J.; Tan, C.H.; Fan, C.C.; Jansen, I.; Savage, J.E.; Witoelar, A.; Wen, N.; Hess, C.P.; Dillon, W.P.; Glastonbury, C.M.; et al. Dissecting the genetic relationship between cardiovascular risk factors and Alzheimer's disease. Acta Neuropathol. 2019, 137, 209-226. [CrossRef]

206. Wang, S.-H.; Yu, T.-Y.; Tsai, F.-C.; Weston, C.J.; Lin, M.-S.; Hung, C.-S.; Kao, H.-L.; Li, Y.-I.; Solé, M.; Unzeta, M.; et al. Inhibition of semicarbazide-sensitive amine oxidase reduces atherosclerosis in apolipoprotein E-deficient mice. Transl. Res. 2018, $197,12-31$. [CrossRef] 
207. Boor, P.J.; Trent, M.B.; Lyles, G.A.; Tao, M.; Ansari, G. Methylamine metabolism to formaldehyde by vascular semicarbazidesensitive amine oxidase. Toxicology 1992, 73, 251-258. [CrossRef]

208. Gubisne-Haberle, D.; Hill, W.; Kazachkov, M.; Richardson, J.S.; Yu, P.H. Protein Cross-Linkage Induced by Formaldehyde Derived from Semicarbazide-Sensitive Amine Oxidase-Mediated Deamination of Methylamine. J. Pharmacol. Exp. Ther. 2004, 310, 1125-1132. [CrossRef]

209. Chen, K.; Maley, J.; Yu, P.H. Potential implications of endogenous aldehydes in ?-amyloid misfolding, oligomerization and fibrillogenesis. J. Neurochem. 2006, 99, 1413-1424. [CrossRef]

210. Chen, K.; Kazachkov, M.; Yu, P.H. Effect of aldehydes derived from oxidative deamination and oxidative stress on $\beta$-amyloid aggregation; pathological implications to Alzheimer's disease. J. Neural Transm. 2007, 114, 835-839. [CrossRef]

211. Qiang, M.; Xiao, R.; Su, T.; Wu, B.-B.; Tong, Z.-Q.; Liu, Y.; He, R.-Q. A novel mechanism for endogenous formaldehyde ele-vation in SAMP8 mouse. J. Alzheimer's Dis. 2014, 40, 1039-1053. [CrossRef]

212. Unzeta, M.; Solé, M.; Boada, M.; Hernández, M. Semicarbazide-sensitive amine oxidase (SSAO) and its possible contribution to vascular damage in Alzheimer's disease. J. Neural Transm. 2007, 114, 857-862. [CrossRef] [PubMed]

213. Jiang, Z.J.; Richardson, J.S.; Yu, P.H. The contribution of cerebral vascular semicarbazide-sensitive amine oxidase to cerebral amyloid angiopathy in Alzheimer's disease. Neuropathol. Appl. Neurobiol. 2008, 34, 194-204. [CrossRef] [PubMed]

214. Rossi, B.; Santos-Lima, B.; Terrabuio, E.; Zenaro, E.; Constantin, G. Common Peripheral Immunity Mechanisms in Multiple Sclerosis and Alzheimer's Disease. Front. Immunol. 2021, 12, 639369. [CrossRef] [PubMed]

215. Baik, S.H.; Cha, M.-Y.; Hyun, Y.-M.; Cho, H.; Hamza, B.; Kim, D.K.; Han, S.-H.; Choi, H.; Kim, K.H.; Moon, M.; et al. Migration of neutrophils targeting amyloid plaques in Alzheimer's disease mouse model. Neurobiol. Aging 2014, 35, 1286-1292. [CrossRef] [PubMed]

216. Zenaro, E.; Pietronigro, E.; Della Bianca, V.; Piacentino, G.; Marongiu, L.; Budui, S.; Turano, E.; Rossi, B.; Angiari, S.; Dusi, S.; et al. Neutrophils promote Alzheimer's disease-like pathology and cognitive decline via LFA-1 integrin. Nat. Med. 2015, 21, 880-886. [CrossRef]

217. Hernández, J.C.C.; Bracko, O.; Kersbergen, C.J.; Muse, V.; Haft-Javaherian, M.; Berg, M.; Park, L.; Vinarcsik, L.K.; Ivasyk, I.; Rivera, D.A.; et al. Neutrophil adhesion in brain capillaries reduces cortical blood flow and impairs memory function in Alzheimer's disease mouse models. Nat. Neurosci. 2019, 22, 413-420. [CrossRef]

218. Pietronigro, E.; Zenaro, E.; Della Bianca, V.; Dusi, S.; Terrabuio, E.; Iannoto, G.; Slanzi, A.; Ghasemi, S.; Nagarajan, R.; Piacentino, G.; et al. Blockade of $\alpha 4$ integrins reduces leukocyte-endothelial interactions in cerebral vessels and improves memory in a mouse model of Alzheimer's disease. Sci. Rep. 2019, 9, 1-15. [CrossRef] [PubMed]

219. Solé, M.; Hernández, M.; Boada, M.; Unzeta, M. Characterization of A7r5 cell line transfected in a stable form by hSSAO/VAP-1 gene (A7r5 hSSAO/VAP-1 cell line). J. Neural Transm. 2007, 114, 763-767. [CrossRef]

220. Solé, M.; Miñano-Molina, A.J.; Unzeta, M. A cross-talk between A $\beta$ and endothelial SSAO/VAP-1 accelerates vascular dam-age and A $\beta$ aggregation related to CAA-AD. Neurobiol. Aging 2015, 36, 762-775. [CrossRef]

221. Sun, P.; Esteban, G.; Inokuchi, T.; Marco-Contelles, J.; Weksler, B.B.; A Romero, I.; O Couraud, P.; Unzeta, M.; Solé, M. Protective effect of the multitarget compound DPH-4 on human SSAO/VAP-1-expressing hCMEC/D3 cells under oxygenglucose deprivation conditions: Anin vitroexperimental model of cerebral ischaemia. Br. J. Pharmacol. 2015, 172, 5390-5402. [CrossRef] [PubMed]

222. Solé, M.; Unzeta, M. Vascular cell lines expressing SSAO/VAP-1: A new experimental tool to study its involvement in vascular diseases. Biol. Cell 2011, 103, 543-557. [CrossRef] [PubMed]

223. Iadecola, C. The overlap between neurodegenerative and vascular factors in the pathogenesis of dementia. Acta Neuropathol. 2010, 120, 287-296. [CrossRef]

224. Solé, M.; Esteban-Lopez, M.; Taltavull, B.; Fábregas, C.; Fadó, R.; Casals, N.; Rodríguez-Álvarez, J.; Miñano-Molina, A.J.; Unzeta, M. Blood-brain barrier dysfunction underlying Alzheimer's disease is induced by an SSAO/VAP-1-dependent cere-brovascular activation with enhanced A $\beta$ deposition. Biochim. et Biophys. Acta (BBA)-Mol. Basis Dis. 2019, 1865, 2189-2202. [CrossRef] [PubMed]

225. Weksler, B.B.; Subileau, E.A.; Perrière, N.; Charneau, P.; Holloway, K.; Leveque, M.; Tricoire-Leignel, H.; Nicotra, A.; Bourdoulous, S.; Turowski, P.; et al. Blood-brain barrier-specific properties of a human adult brain endothelial cell line. FASEB J. 2005, 19, 1872-1874. [CrossRef] [PubMed]

226. Honig, L.S.; Kukull, W.; Mayeux, R. Atherosclerosis and AD: Analysis of data from the US National Alzheimer's Coordinating Center. Neurology 2005, 64, 494-500. [CrossRef] [PubMed]

227. Goulay, R.; Romo, L.M.; Hol, E.M.; Dijkhuizen, R.M. From Stroke to Dementia: A Comprehensive Review Exposing Tight Interactions Between Stroke and Amyloid- $\beta$ Formation. Transl. Stroke Res. 2020, 11, 601-614. [CrossRef] [PubMed]

228. Zhou, J.; Yu, J.-T.; Wang, H.-F.; Meng, X.-F.; Tan, C.-C.; Wang, J.; Wang, C.; Tan, L. Association between stroke and Alz-heimer's disease: Systematic review and meta-analysis. J. Alzheimer's Dis. 2015, 43, 479-489. [CrossRef] [PubMed]

229. Vijayan, M.; Reddy, P.H. Stroke, Vascular Dementia, and Alzheimer's Disease: Molecular Links. J. Alzheimer's Dis. 2016, 54, 427-443. [CrossRef]

230. Shi, J.; Yang, S.; Stubley, L.; Day, A.; Simpkins, J. Hypoperfusion induces overexpression of $\beta$-amyloid precursor protein mRNA in a focal ischemic rodent model. Brain Res. 2000, 853, 1-4. [CrossRef] 
231. Nihashi, T.; Inao, S.; Kawai, T.; Sugimoto, T.; Niwa, M.; Hata, N.; Hayashi, S.; Yoshida, J.; Kajita, Y.; Kabeya, R. Expression and Distribution of Beta Amyloid Precursor Protein and Beta Amyloid Peptide in Reactive Astrocytes After Transient Middle Cerebral Artery Occlusion. Acta Neurochir. 2001, 143, 287-295. [CrossRef] [PubMed]

232. Stephenson, D.T.; Rash, K.; Clemens, J.A. Amyloid precursor protein accumulates in regions of neurodegeneration following focal cerebral ischemia in the rat. Brain Res. 1992, 593, 128-135. [CrossRef]

233. Kalaria, R.N.; Bhatti, S.U.; Palatinsky, E.A.; Pennington, D.H.; Shelton, E.R.; Chan, H.W.; Perry, G.; Lust, W.D. Accumulation of the $\beta$ amyloid precursor protein at sites of ischemic injury in rat brain. NeuroReport 1993, 4, 211-214. [CrossRef] [PubMed]

234. Badan, I.; Dinca, I.; Buchhold, B.; Suofu, Y.; Walker, L.C.; Gratz, M.; Platt, D.H.; Kessler, C.; Popawagner, A. Accelerated accumulation of $\mathrm{N}$ - and C-terminal betaAPP fragments and delayed recovery of microtubule-associated protein $1 \mathrm{~B}$ expression following stroke in aged rats. Eur. J. Neurosci. 2004, 19, 2270-2280. [CrossRef]

235. Van Groen, T.; Puurunen, K.; Mäki, H.-M.; Sivenius, J.; Jolkkonen, J. Transformation of Diffuse $\beta$-Amyloid Precursor Protein and $\beta$-Amyloid Deposits to Plaques in the Thalamus After Transient Occlusion of the Middle Cerebral Artery in Rats. Stroke 2005, 36, 1551-1556. [CrossRef] [PubMed]

236. Mäkinen, S.; Van Groen, T.; Clarke, J.; Thornell, A.; Corbett, D.; Hiltunen, M.; Soininen, H.; Jolkkonen, J. Coaccumulation of Calcium and $\beta$-Amyloid in the Thalamus after Transient Middle Cerebral Artery Occlusion in Rats. Br. J. Pharmacol. 2007, 28, 263-268. [CrossRef] [PubMed]

237. Hiltunen, M.; Mäkinen, P.; Peräniemi, S.; Sivenius, J.; Van Groen, T.; Soininen, H.; Jolkkonen, J. Focal cerebral ischemia in rats alters APP processing and expression of A $\beta$ peptide degrading enzymes in the thalamus. Neurobiol. Dis. 2009, 35, 103-113. [CrossRef] [PubMed]

238. Sun, X.; He, G.; Qing, H.; Zhou, W.; Dobie, F.; Cai, F.; Staufenbiel, M.; Huang, L.E.; Song, W. Hypoxia facilitates Alzheimer's disease pathogenesis by up-regulating BACE1 gene expression. Proc. Natl. Acad. Sci. USA 2006, 103, 18727-18732. [CrossRef] [PubMed]

239. Zhang, X.; Zhou, K.; Wang, R.; Cui, J.; Lipton, S.A.; Liao, F.-F.; Xu, H.; Zhang, Y.-W. Hypoxia-inducible Factor $1 \alpha$ (HIF-1 $\alpha$ )mediated Hypoxia Increases BACE1 Expression and $\beta$-Amyloid Generation. J. Biol. Chem. 2007, 282, 10873-10880. [CrossRef]

240. Guglielmotto, M.; Aragno, M.; Autelli, R.; Giliberto, L.; Novo, E.; Colombatto, S.; Danni, O.; Parola, M.; Smith, M.A.; Perry, G.; et al. The up-regulation of BACE1 mediated by hypoxia and ischemic injury: Role of oxidative stress and HIF1 $\alpha$. J. Neurochem. 2009, 108, 1045-1056. [CrossRef]

241. Nalivaevaa, N.N.; Fisk, L.; Kochkina, E.G.; Plesneva, S.A.; Zhuravin, I.A.; Babusikova, E.; Dobrota, D.; Turner, A.J. Effect of Hypoxia/Ischemia and Hypoxic Preconditioning/Reperfusion on Expression of Some Amyloid-Degrading Enzymes. Ann. N. Y. Acad. Sci. 2004, 1035, 21-33. [CrossRef] [PubMed]

242. Fisk, L.; Nalivaeva, N.N.; Boyle, J.P.; Peers, C.S.; Turner, A.J. Effects of Hypoxia and Oxidative Stress on Expression of Neprilysin in Human Neuroblastoma Cells and Rat Cortical Neurones and Astrocytes. Neurochem. Res. 2007, 32, 1741-1748. [CrossRef] [PubMed]

243. Zhang, X.; Le, W. Pathological role of hypoxia in Alzheimer's disease. Exp. Neurol. 2010, 223, 299-303. [CrossRef] [PubMed]

244. Pichiule, P.; Chavez, J.C.; Schmidt, A.M.; Vannucci, S.J. Hypoxia-inducible Factor-1 Mediates Neuronal Expression of the Receptor for Advanced Glycation End Products following Hypoxia/Ischemia. J. Biol. Chem. 2007, 282, 36330-36340. [CrossRef] [PubMed]

245. Chen, G.-J.; Xu, J.; LaHousse, S.A.; Caggiano, N.L.; De La Monte, S.M. Transient hypoxia causes Alzheimer-type molecular and biochemical abnormalities in cortical neurons: Potential strategies for neuroprotection1. J. Alzheimer's Dis. 2003, 5, 209-228. [CrossRef] [PubMed]

246. Wen, Y.; Yang, S.; Liu, R.; Brun-Zinkernagel, A.M.; Koulen, P.; Simpkins, J.W. Transient Cerebral Ischemia Induces Aberrant Neuronal Cell Cycle Re-entry and Alzheimer's Disease-like Tauopathy in Female Rats. J. Biol. Chem. 2004, $279,22684-22692$. [CrossRef] [PubMed]

247. Kinnecom, C.; Lev, M.H.; Wendell, L.; Smith, E.E.; Rosand, J.; Frosch, M.P.; Greenberg, S.M. Course of cerebral amyloid angiopathy-related inflammation. Neurology 2007, 68, 1411-1416. [CrossRef] [PubMed]

248. Zlokovic, B.V. New therapeutic targets in the neurovascular pathway in Alzheimer's disease. Neurotherapeutics 2008, 5, 409-414. [CrossRef] [PubMed]

249. Wojtunik-Kulesza, K.A.; Oniszczuk, A.; Oniszczuk, T.; Waksmundzka-Hajnos, M. The influence of common free radicals and antioxidants on development of Alzheimer's Disease. Biomed. Pharmacother. 2016, 78, 39-49. [CrossRef] [PubMed]

250. Sun, M.-S.; Jin, H.; Sun, X.; Huang, S.; Zhang, F.-L.; Guo, Z.-N.; Yang, Y. Free Radical Damage in Ischemia-Reperfusion Injury: An Obstacle in Acute Ischemic Stroke after Revascularization Therapy. Oxidative Med. Cell. Longev. 2018, 2018, 1-17. [CrossRef]

251. Attems, J.; Jellinger, K.A. The overlap between vascular disease and Alzheimer's disease-Lessons from pathology. BMC Med. 2014, 12, 1-12. [CrossRef]

252. Han, B.H.; Zhou, M.-L.; Johnson, A.W.; Singh, I.; Liao, F.; Vellimana, A.K.; Nelson, J.W.; Milner, E.; Cirrito, J.R.; Basak, J.; et al Contribution of reactive oxygen species to cerebral amyloid angiopathy, vasomotor dysfunction, and microhemorrhage in aged Tg2576 mice. Proc. Natl. Acad. Sci. USA 2015, 112, E881-E890. [CrossRef]

253. Freeze, W.M.; Bacskai, B.J.; Frosch, M.P.; Jacobs, H.I.; Backes, W.H.; Greenberg, S.M.; Van Veluw, S.J. Blood-Brain Barrier Leakage and Microvascular Lesions in Cerebral Amyloid Angiopathy. Stroke 2019, 50, 328-335. [CrossRef] [PubMed]

254. Vinters, H.V.; Gilbert, J.J. Cerebral amyloid angiopathy: Incidence and complications in the aging brain. II. The distribution of amyloid vascular changes. Stroke 1983, 14, 924-928. [CrossRef] [PubMed] 
255. Attems, J.; Jellinger, K.; Thal, D.; Van Nostrand, W. Review: Sporadic cerebral amyloid angiopathy. Neuropathol. Appl. Neurobiol. 2010, 37, 75-93. [CrossRef] [PubMed]

256. Marco, S.; Skaper, S.D. Amyloid $\beta$-peptide1-42 alters tight junction protein distribution and expression in brain microvessel endothelial cells. Neurosci. Lett. 2006, 401, 219-224. [CrossRef] [PubMed]

257. Carrano, A.; Hoozemans, J.J.; Van Der Vies, S.M.; Rozemuller, A.J.; Van Horssen, J.; De Vries, H.E. Amyloid Beta Induces Oxidative Stress-Mediated Blood-Brain Barrier Changes in Capillary Amyloid Angiopathy. Antioxid. Redox Signal. 2011, 15, 1167-1178. [CrossRef]

258. Zipfel, G.J.; Han, H.; Ford, A.L.; Lee, J.-M. Cerebral Amyloid Angiopathy: Progressive Disruption of the Neurovascular Unit. Stroke 2008, 40, S16-S19. [CrossRef] [PubMed]

259. Park, L.; Uekawa, K.; Garcia-Bonilla, L.; Koizumi, K.; Murphy, M.; Pistik, R.; Younkin, L.; Younkin, S.; Zhou, P.; Carlson, G.; et al. Brain Perivascular Macrophages Initiate the Neurovascular Dysfunction of Alzheimer A $\beta$ Peptides. Circ. Res. 2017, 121, 258-269. [CrossRef] [PubMed]

260. Giri, R.; Shen, Y.; Stins, M.; Du Yan, S.; Schmidt, A.M.; Stern, D.; Kim, K.-S.; Zlokovic, B.; Kalra, V.K. $\beta$-Amyloid-induced migration of monocytes across human brain endothelial cells involves RAGE and PECAM-1. Am. J. Physiol. Physiol. 2000, 279, C1772-C1781. [CrossRef]

261. Hartz, A.M.; Bauer, B.; Soldner, E.L.; Wolf, A.; Boy, S.; Backhaus, R.; Mihaljevic, I.; Bogdahn, U.; Klünemann, H.H.; Schuierer, G.; et al. Amyloid- $\beta$ Contributes to Blood-Brain Barrier Leakage in Transgenic Human Amyloid Precursor Protein Mice and in Humans with Cerebral Amyloid Angiopathy. Stroke 2012, 43, 514-523. [CrossRef] [PubMed]

262. Carrano, A.; Hoozemans, J.J.; Van Der Vies, S.M.; Van Horssen, J.; De Vries, H.E.; Rozemuller, A.J. Neuroinflammation and Blood-Brain Barrier Changes in Capillary Amyloid Angiopathy. Neurodegener. Dis. 2012, 10, 329-331. [CrossRef] [PubMed]

263. Schreibelt, G.; Kooij, G.; Reijerkerk, A.; Van Doorn, R.; Gringhuis, S.I.; Van Der Pol, S.; Weksler, B.B.; Romero, I.A.; Couraud, P.; Piontek, J.; et al. Reactive oxygen species alter brain endothelial tight junction dynamics via RhoA, PI3 kinase, and PKB signaling. FASEB J. 2007, 21, 3666-3676. [CrossRef] [PubMed]

264. Ghiso, J.; Fossati, S.; Rostagno, A. Amyloidosis Associated with Cerebral Amyloid Angiopathy: Cell Signaling Pathways Elicited in Cerebral Endothelial Cells. J. Alzheimer's Dis. 2014, 42, S167-S176. [CrossRef] [PubMed]

265. Gireud-Goss, M.; Mack, A.F.; McCullough, L.D.; Urayama, A. Cerebral Amyloid Angiopathy and Blood-Brain Barrier Dysfunction. Neuroscientist 2020. [CrossRef] [PubMed]

266. Terry, A.V.; Buccafusco, J.J.; Wilson, C. Cognitive dysfunction in neuropsychiatric disorders: Selected serotonin receptor subtypes as therapeutic targets. Behav. Brain Res. 2008, 195, 30-38. [CrossRef] [PubMed]

267. Wang, L.; Esteban, G.; Ojima, M.; Bautista-Aguilera, O.M.; Inokuchi, T.; Moraleda, I.; Iriepa, I.; Samadi, A.; Youdim, M.B.; Romero, A.; et al. Donepezil + propargylamine + 8-hydroxyquinoline hybrids as new multifunctional metal-chelators, ChE and MAO inhibitors for the potential treatment of Alzheimer's disease. Eur. J. Med. Chem. 2014, 80, 543-561. [CrossRef]

268. Davies, P. Selective Loss of Central Cholinergic Neurons in Alzheimer's Disease. Lancet 1976, 308, 1403. [CrossRef]

269. Geula, C.; Mesulam, M. Cholinergic systems in Alzheimer's disease. In: Terry RD, Katzman R, Bick KL, Sisodia SS, editors. Alzheimer Dis. 1999, 2, 269-292.

270. Buccafusco, J.J.; Terry, A.V., Jr. Multiple central nervous system targets for eliciting beneficial effects on memory and cogni-tion. J. Pharmacol. Exp. Ther. 2000, 295, 438-446.

271. Youdim, M.B.H.; Buccafusco, J.J. CNS Targets for multi-functional drugs in the treatment of Alzheimer?s and Parkinson?s diseases. J. Neural Transm. 2005, 112, 519-537. [CrossRef] [PubMed]

272. Cavalli, A.; Bolognesi, M.L.; Minarini, A.; Rosini, M.; Tumiatti, V.; Recanatini, M.; Melchiorre, C. Multi-target-Directed Ligands To Combat Neurodegenerative Diseases. J. Med. Chem. 2008, 51, 347-372. [CrossRef] [PubMed]

273. Eunzeta, M.; Eesteban, G.; Ebolea, I.; Fogel, W.A.; Ramsay, R.; Youdim, M.B.H.; Tipton, K.F.; Emarco-Contelles, J. Multi-Target Directed Donepezil-Like Ligands for Alzheimer's Disease. Front. Neurosci. 2016, 10, 205. [CrossRef]

274. Bernabé, M.; Fernández-Alvarez, E.; Lora-Tamayo, M.; Nieto, O. [Potential psychotropic drugs. V. Monoamine oxidase inhibitors. Preparation and study of some indolyl-3 alkyl-hydrazines]. Bull. de la Soc. Chim. de Fr. 1971, 5, 1882-1887.

275. Monge, A.; Palop, J.A.; Goñí, T.; Martínez, A.; Fernandez-Alvarez, E. About the synthesis of [1,2]diazepinoindole derivatives from ethyl 2-(1-methylindole)acetate, 2-indole and 3-indoleacetohydrazones. J. Heterocycl. Chem. 1985, 22, 1445-1451. [CrossRef]

276. Wang, Q.; Yan, J.; Chen, X.; Li, J.; Yang, Y.; Weng, J.; Deng, C.; Yenari, M.A. Statins: Multiple neuroprotective mechanisms in neurodegenerative diseases. Exp Neurol 2011, 230, 27-34. [CrossRef] [PubMed]

277. Li, Q.; Zhuang, Q.K.; Yang, J.N.; Zhang, Y.Y. Statins excert neuroprotection on cerebral ischemia independent of their li-pidlowering action: The potential molecular mechanisms. Eur. Rev. Med. Pharmacol Sci. 2014, 18, 1113-1126.

278. García-Bonilla, L.; Campos, M.; Giralt, D.; Salat, D.; Chacón, P.; Hernández-Guillamon, M.; Rosell, A.; Montaner, J. Evidence for the efficacy of statins in animal stroke models: A meta-analysis. J. Neurochem. 2012, 122, 233-243. [CrossRef] [PubMed] 